\title{
Changing Patterns of Temperature in Yobe State, North-Eastern Nigeria: An Evidence of Climate Change
}

\author{
O. Musa Kehinde ${ }^{1}$, Bulama Lawan ${ }^{2^{\star}}$ and A. Ahmad Umar ${ }^{3}$ \\ ${ }^{1}$ Department of Geography, Usman Danfodio University, Sokoto State, Nigeria. \\ ${ }^{2}$ Department of Geography, Federal University Gashua, Yobe State, Nigeria. \\ ${ }^{3}$ Umar Suleiman College of Education, Gashua, Yobe State, Nigeria.
}

\begin{abstract}
Authors' contributions
This work was carried out in collaboration among all authors. Author OMK designed the study, performed the statistical analysis, wrote the protocol and wrote the first draft of the manuscript. Authors BL and AAU managed the analyses of the study. Author BL managed the literature searches. All authors read and approved the final manuscript.
\end{abstract}

Article Information

DOI: $10.9734 / A J G R / 2021 / v 4 i 130126$

Editor(s):

(1) Dr. Hani Rezgallah Al-Hamed Al-Amoush, Al Al-Bayt University, Jordan.

Reviewers:

(1) Bakht Amin, Northwest Agriculture and Forestry University, China.

(2) Jesús G. Rodríguez Diego, Universidad Autónoma Metropolitana-Xochimilco (UAM-X), Mexico.

Complete Peer review History: http://www.sdiarticle4.com/review-history/66372

Original Research Article

Received 10 January 2021

Accepted 13 March 2021

Published 03 April 2021

\begin{abstract}
Air temperature is one of the fundamental indicators of Climate Change in any place on earth. Understanding the changing patterns of air temperature in Yobe State is instrumental in establishing the manifestation of Climate Change in the area and to enables the policy makers to design the best mechanisms to cope with the vagaries of increasing temperature. This study examined the changing patterns of temperature in Yobe State as an evidence of Climate Change. The study used mean monthly minimum and maximum air temperature data collected from the archives of the Nigerian Meteorological Agency (NIMET) with respect to Nguru and Potiskum weather stations in the State for a period of 1956-2015. The data was analyzed using descriptive statistics, linear regression trend lines and coefficient of variation (C.V). The result showed that April is the hottest month with the highest mean maximum temperatures of $39.6^{\circ} \mathrm{C}$ and $38.6^{\circ} \mathrm{C}$ in Nguru and Potiskum respectively while January is the coldest month with mean temperatures of $30.5^{\circ} \mathrm{C}$ and $30.8^{\circ} \mathrm{C}$ for $\mathrm{Nguru}$ and Potiskum respectively. Further finding revealed that temperatures are highly variable in February in
\end{abstract}


both Nguru and Potiskum with C.V of $8.7 \%$ and $5.7 \%$ and less variable in October with C.V of $2.0 \%$. Finding showed that in general term, there were upward trends in monthly and annual positive temperature anomalies ranging from $0.2^{\circ} \mathrm{C}$ to as high as $4.0^{\circ} \mathrm{C}$ in some months and years in the state. The study concludes that temperatures in Yobe State have witnessed series of changes within the 60 years period. Therefore, it is suggested that stakeholders in the Yobe State Environmental Protection Agency should intensify efforts in reducing deforestation while encouraging people on afforestation with a view to reducing the impact of Greenhouse gases that are contributing to more warming than normal. There should be adequate electricity and water supply for immediate relieve from excessive heat emanating from high temperature.

Keywords: Temperature; climate change; pattern.

\section{INTRODUCTION}

Climate Change has been a global challenge in the recent time. It is clear to environment experts and scientists that changes in the global climate is due to the surge in the Greenhouse Gases emission, which are trapping more heat [1]. Apart from rainfall, air temperature is the next prominent climatic variable that has been used as an indicator of global warming and Climate Change in any place on earth [2]. Temperature has been defined as the degree of hotness and coldness of a place or environment. Therefore, its study is very crucial to monitor the Climate Change and because its intensity has a greater impact on human and natural phenomenon on the earth's surface.

The differences in temperature from place to place, season to season, between day and night are consequences of the intensity of the sunlight at different places, seasons and time of the day. The temperatures on earth have been exacerbated by continuous emissions of greenhouse gases which trap more heat. According to the report of IPCC [3], the global mean surface air temperature has increased by $0.74^{\circ} \mathrm{C}$ during the last century. Another report has it that the global temperatures have increased during the last 30 years and 2001 to 2010 was the warmest decade ever recorded [4]. Many other researchers have proved that the earth is becoming hotter. According to Denchak [5], the years 2000 to 2009 was hotter than any other decade in the past 1, 300 years. As the earth warms up, heat waves are becoming more common in many places, including Nigeria. The rise in the World temperature by $1.5^{\circ} \mathrm{C}$ above the pre-industrial era will have greater impact on land, biodiversity and ecosystem, including species loss and extinction. This will cause greater risks to heat, livelihood, food security, water supply, human security and economic growth [6]. A warmer climate creates an atmosphere that can collect, retain and drop more water, changing the weather patterns in such a way that the wet areas becoming wetter while the dry areas becoming drier.

Sub-Saharan African countries have been portrayed as the most vulnerable region to the impact of global Climate Change because of their reliance on agriculture that is sensitive to weather and climate variability [7]. It is evident from the review of Kotir, [8] that the climate of Africa is already exhibiting significant changes as a result of changes in the average temperature. Many researchers have studied temperature trend, spatial and temporal patterns in Nigeria and found that the country is getting warmer $[9,10,11,12,13]$. Yobe State is one of the Sudano-Sahelian regions of Nigeria that has been ravaged by Climate Change. Therefore, the patterns at which the temperature changes over the years are critical in designing the best mitigation measures in the place. Earlier studies related to Climate Change in the area $[14,15,16,17]$ have not focused on the "changing patterns of temperature". This study covers the gap in literature by examining the changing patterns of temperature in Yobe State with a view to further establishing the reality of Climate Change.

\section{MATERIALS AND METHODS}

Yobe State is a State located in the northeastern Nigeria. It lies approximately between Latitude $12^{\circ} 00^{\prime} \mathrm{N}$ and $12.000^{\circ} \mathrm{N}$ of the equator and between Longitude $11^{\circ} 30^{\prime} \mathrm{E}$ and $11.500^{\circ} \mathrm{E}$ of the Greenwich Meridian. It occupies a total landmass of $45,502 \mathrm{~km}^{2}$ with a total population of 2 , 321,339 [18]. The estimated population growth as at 2011 was $2,757,000$. The State borders four States: Bauchi, Burno, Gombe and Jigawa. It borders to the north by Diffa and Zinder 
Regions of Niger. Because the State lies in the Sahel Savanna belt, the weather conditions are hot and dry for most of the year, except in the Southern part of the State which has more annual rainfall [19]. The climate is characteristically marked by two seasons namely: dry and wet season. The rainy season starts in May or June in the southern part and June or July in the northern flank and peaks in August and finishes quite rapidly in September or October. The rainfall in the state is mostly influenced by the migration of the Inter-Tropical Discontinuity (ITD) [20,21].

The economy of the State is majorly agriculture. It is also rich in mineral deposit, including Gypsum and Kaolin in Fune Local Government and very rich in agricultural resources as well. The State agricultural produce includes gum Arabic, groundnut, beans and cotton. The State also has the biggest cattle markets in West Africa, located in Potiskum. The major ethnic groups living in the State are the Kanuri and Fulani, while other major ethnic communities include Bolewa, Ngizim, Karai-Karai, Bade, Hausa, Ngamo, Shuma, Bura, Margi and Manga [19].

\subsection{Method of Analysis}

The study used mean monthly maximum and minimum air temperatures for a period of 1956 to 2015. Yobe State has two major Weather stations, which are Nguru and Potiskum. Nguru is situated on Latitude $12.88^{\circ} \mathrm{N}$ of the equator and Longitude $10.47^{\circ} \mathrm{E}$ of the Greenwich Meridian while Potiskum is located on Latitude $11.7^{\circ} \mathrm{N}$ of the equator and Longitude $11.03^{\circ} \mathrm{E}$ of the Greenwich Meridian (NIMET Seasonal Rainfall Prediction 2020). The data were sourced from the archives of the Nigerian Meteorological Agency (NIMET). The data were analyzed using descriptive statistics such as mean, Standard deviation, coefficient of variation (C.V) and linear regression trend lines. The C.V was calculated via the formula:

$$
\begin{aligned}
& \text { C.V }=\sigma / X \times 100 \text { where: } \\
& \text { C. } V=\text { Coefficient of Variation } \\
& \sigma=\text { standard Deviation } \\
& X=\text { Mean }
\end{aligned}
$$

The whole analysis was done with the aid of Microsoft excel software for better accuracy. The results were presented in tables and charts for better understanding.

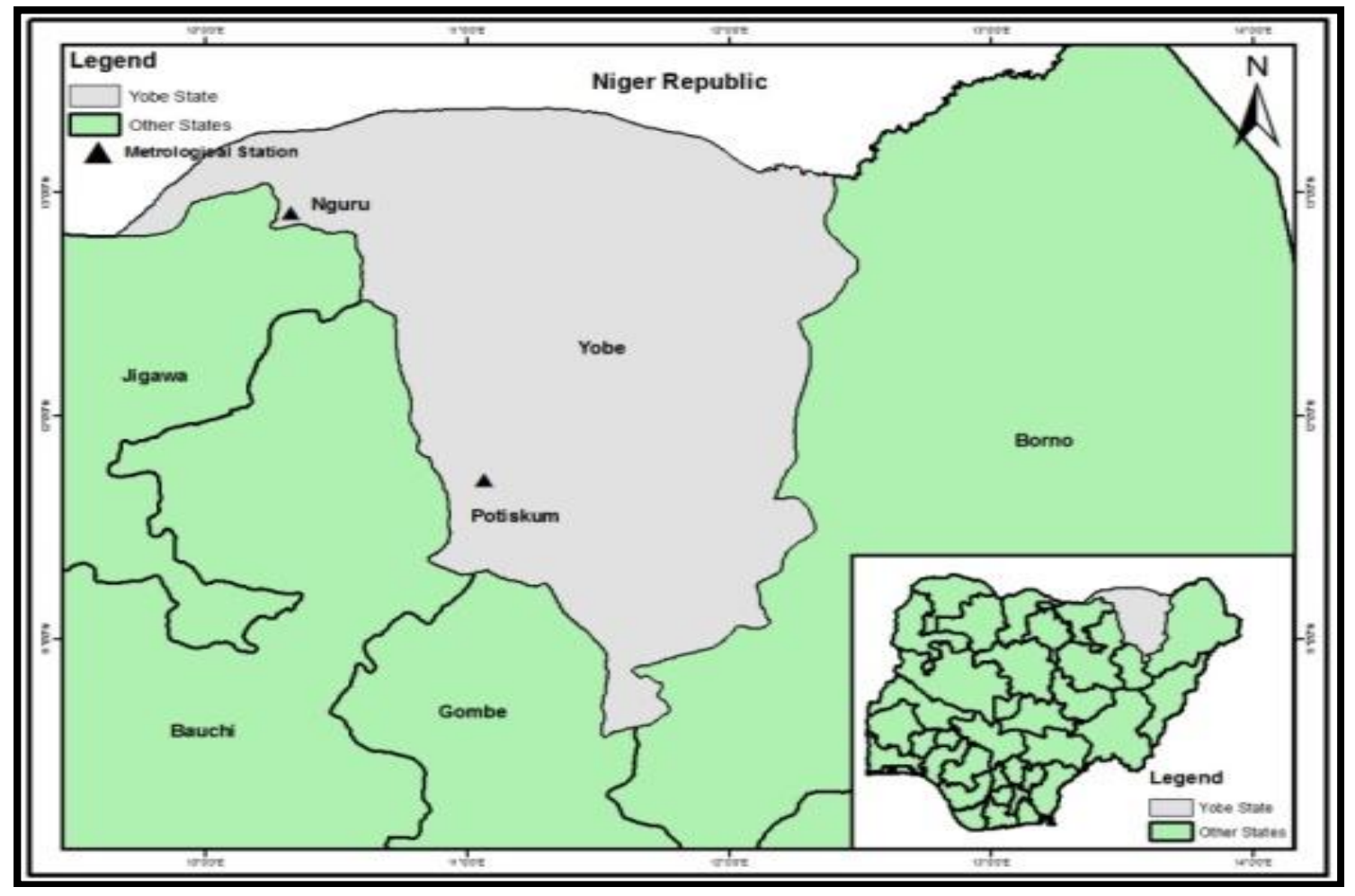

Fig. 1. Map of the study area

Source: GIS Lab. FUGA Geography Department 


\section{RESULTS AND DISCUSSION}

\subsection{Monthly Temperature and Changing Pattern in Yobe}

Its

The result in Image 1 showed that the month of April recorded the highest mean maximum temperature of $39.6^{\circ} \mathrm{C}$ while the highest mean minimum temperature $\left(25.6^{\circ} \mathrm{C}\right)$ was recorded in the month of May in Nguru during the period (1956-2015). Likewise, the lowest mean maximum and minimum temperatures were recorded in the month of January with values of $30.5^{\circ} \mathrm{C}$ and $13.4^{\circ} \mathrm{C}$ respectively. In addition, the highest mean maximum and highest minimum temperatures were recorded in the month of April in Potiskum with values of $38.6^{\circ} \mathrm{C}$ and $23.98^{\circ} \mathrm{C}$ respectively. In the same vein, the lowest mean maximum and lowest mean minimum temperature of $30.8^{\circ} \mathrm{C}$ and $13.4^{\circ} \mathrm{C}$ were recorded respectively during the month of January in Potiskum. This implies that the month of April remains the hottest month in Yobe while the month of January remains the coldest month in Yobe State. Factors such as the prevailing air masses, which determine the seasons in Nigeria, the movement of ITDZ, the location of the area being in the Semi-arid region of Nigeria that is characterized with cloudless sky, longer duration of sunshine hours, plain terrain, etc are responsible for high air temperature in the place. It is also important to note that the coldest temperature during the month of colder temperatures experienced during the months of January and December were attributed to the influence of the domination of harmattan wind [16].

This finding is in line with the findings of the Nigerian Meteorological Agency (NIMET's Quarterly Weather Review, 2013) [22] which stated that the lowest maximum temperature of between $31.0^{\circ} \mathrm{C}$ and $34.0^{\circ} \mathrm{C}$ were recorded in the northeastern part of Nigeria in January. It further stressed that the lowest minimum temperatures values prevailed over the northeastern part of Nigeria $13.0^{\circ} \mathrm{C}-17.0^{\circ} \mathrm{C}$ in January. Likewise, places like Gusau, Sokoto, Yobe, etc recorded the highest maximum temperature ranging from $36.0^{\circ} \mathrm{C} \quad-39.0^{\circ} \mathrm{C}$ and the lowest minimum temperature of $14.0-18.0^{\circ} \mathrm{C}$ in February. The NIMET's quarterly Weather Review for March reported that places in the north including Yobe recorded the highest maximum and minimum temperatures between $38.0-42.0^{\circ} \mathrm{C}$. This finding is also in tandem with the NiMET's Agrometeorological Bulleting (April to June,
2012) [23] which also reported similar monthly minimum and maximum temperature values from January to April. This finding is in line with the predicted mean monthly temperatures in the Seasonal Rainfall Prediction for the year 2017 and 2020. The daytime temperatures for the months of January, February, March and April in Nguru were predicted to be $30.3^{\circ} \mathrm{C}, 34.0^{\circ} \mathrm{C}$, $37.9^{\circ} \mathrm{C}$ and $40.7^{\circ} \mathrm{C}$ respectively. On the other hand, night temperatures for January, February, March and April were also predicted to be $13.9^{\circ} \mathrm{C}, 16.6^{\circ} \mathrm{C}, 20.7^{\circ} \mathrm{C}$ and $24.3^{\circ} \mathrm{C}$ respectively. The daytime temperatures for Potiskum in 2017 for January, February, March and April were predicted to be $30.8^{\circ} \mathrm{C}, 34.0^{\circ} \mathrm{C}, 37.9^{\circ} \mathrm{C}$ and $40.1^{\circ} \mathrm{C}$ while the nighttime temperatures in the same months were predicted to be $13.0^{\circ} \mathrm{C}$, $16.1^{\circ} \mathrm{C}, \quad 20.5^{\circ} \mathrm{C}$ and $24.5^{\circ} \mathrm{C}$ respectively. Similarly, the predicted daytime temperatures for Nguru from January to April 2020 were predicted to be $30.5^{\circ} \mathrm{C}, 34.1^{\circ} \mathrm{C}, 38.0^{\circ} \mathrm{C}$ and $40.7^{\circ} \mathrm{C}$ respectively while that of Potiskum were predicted to be $30.9^{\circ} \mathrm{C}, 34.0^{\circ} \mathrm{C}, 38.0^{\circ} \mathrm{C}$ and $40.7^{\circ} \mathrm{C}$.

\subsection{Monthly Temperature Variability in Yobe}

The result in Table 1 revealed that the monthly minimum and maximum temperatures were more variable and less stable during the month of February in Nguru over the period (1956-2015) with the highest coefficient of variation $(8.7 \%$ and $5.7 \%$ ) respectively. In contrast, the minimum temperature was less variable during the month of September while the maximum temperature was less variable during the month of October with C. $V$ values of $(2.3 \%$ and $2.0 \%)$ respectively. This implies that the minimum and maximum temperatures were more severe during the months of September and October respectively as against the month of February in Nguru. This variability is a strong indication of Climate Change in the area.

It could also be inferred from Table 2 that both the minimum and maximum temperatures were highly variable during the month of February in Potiskum with the highest C. $V$ values of $8.4 \%$ and $5.8 \%$ ) respectively. It is also obvious from the table that the minimum temperature was less variable during the month of September $(2.4 \%)$ while the maximum temperature was less variable during the month of October $(2.0 \%)$ in Potiskum. This indicates that temperature is more variable, less stable during the month of February, less variable and more stable during 
the months of September and October in Yobe State.

This finding is in line with the findings of the NIMET's Quarterly Weather Review 2013 [22]; NIMET's Agromet Bulletin 2012 [23] which revealed how the maximum and minimum temperatures vary across Nigeria on monthly basis. This finding also conforms to the finding of Zembe et al. [17] which stated that the average maximum temperature was calculated to be $44.2^{\circ} \mathrm{C}$ (in 1983) meaning the diurnal temperature can be as high as between $45-47^{\circ} \mathrm{C}$, especially during the hotter months of April and May. The standard deviation and variance of $2.84^{\circ} \mathrm{C}$ and $8.11^{\circ} \mathrm{C}$ respectively are indications that the temperature showed an increasing trend $\left(0.024^{\circ} \mathrm{C}\right)$ which implies warmer than normal temperature in the area.

\subsection{Monthly Anomaly of Maximum Temperature in Yobe}

The result in Figs. 4 to 15 showed that all the months except January, February and December experienced upward trends in their temperature anomalies in Yobe over the period (1956-2015). This implies that the monthly temperatures in Yobe have been warmer than normal from March to November while they were cooler than normal in January, February and December during the period. Further analysis from Fig. 6 showed that

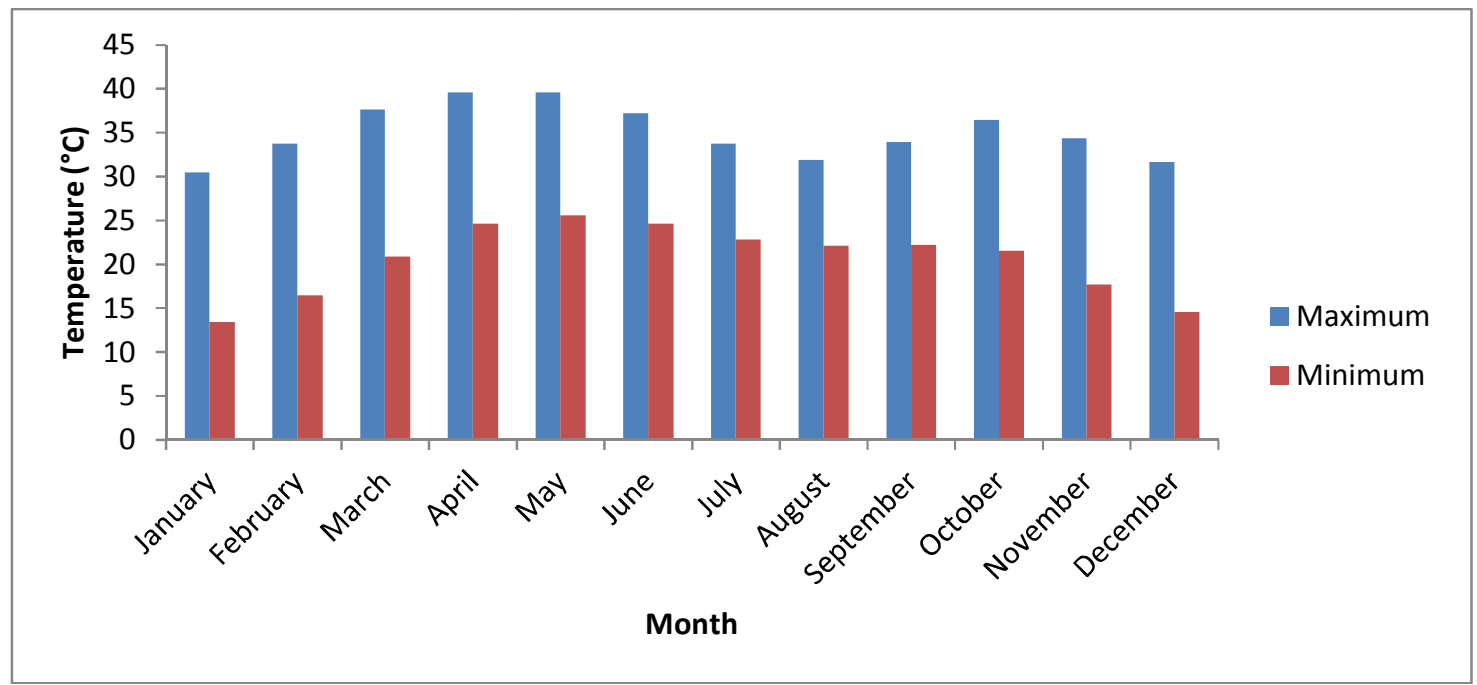

Fig. 2. Mean monthly temperature for Nguru (1956-2015) Source: Authors' Fieldwork, 2021

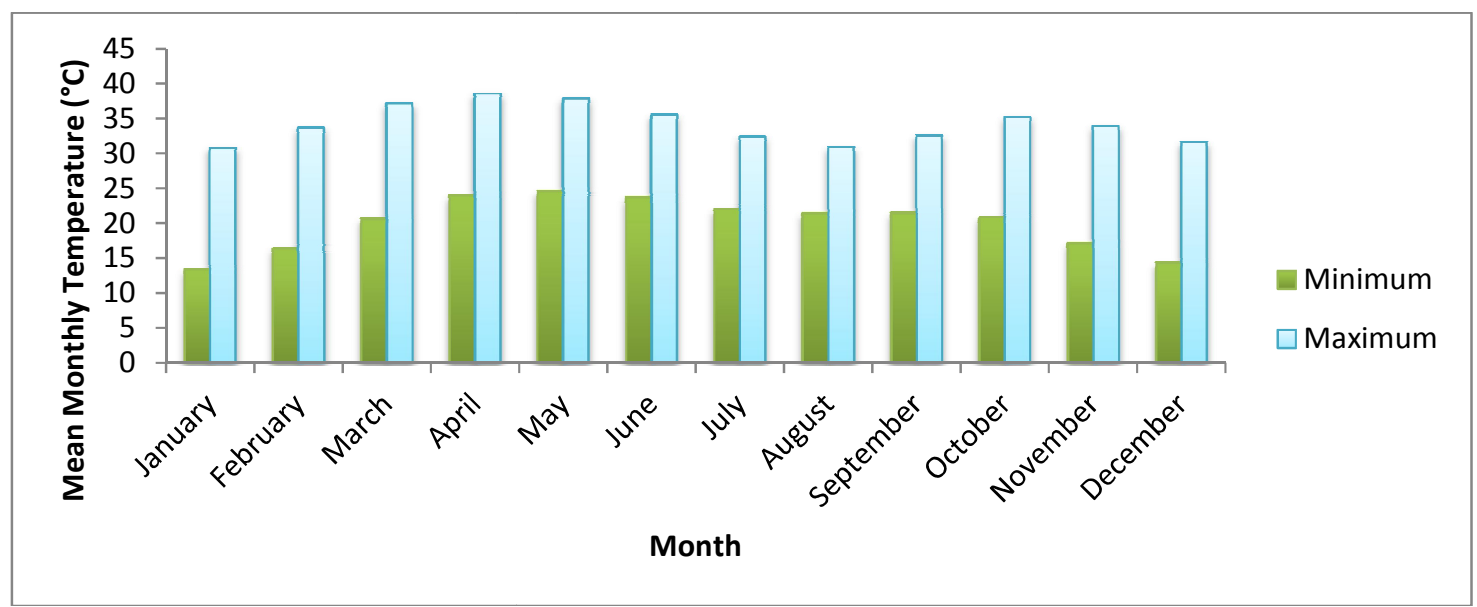

Fig. 3. Mean Monthly Temperature for Potiskum (1956-2015) Source: Authors' Fieldwork, 2021 
Table 1. Monthly variation of temperature in Nguru (1956-2015)

\begin{tabular}{lllll}
\hline Month & Temperature & Mean $\left({ }^{\circ} \mathbf{C}\right)$ & Std. Deviation $\left({ }^{\circ} \mathbf{C}\right)$ & $\mathbf{C . V}\left({ }^{\circ} \mathbf{C}\right)$ \\
\hline January & Maximum & 30.49 & 1.702 & 5.6 \\
February & Minimum & 13.40 & 1.105 & 8.3 \\
& Maximum & 33.74 & 1.933 & 5.7 \\
March & Minimum & 16.46 & 1.438 & 8.7 \\
& Maximum & 37.66 & 1.537 & 4.1 \\
April & Minimum & 20.86 & 1.219 & 5.8 \\
& Maximum & 39.58 & 0.962 & 2.4 \\
May & Minimum & 24.63 & 0.971 & 3.9 \\
& Maximum & 39.55 & 0.919 & 2.3 \\
June & Minimum & 25.57 & 0.845 & 3.3 \\
& Maximum & 37.18 & 0.981 & 2.6 \\
July & Minimum & 24.64 & 0.764 & 3.1 \\
\multirow{3}{*}{ August } & Maximum & 33.76 & 1.158 & 3.4 \\
\multirow{2}{*}{ September } & Minimum & 22.83 & 0.787 & 3.4 \\
& Maximum & 31.89 & 1.182 & 3.7 \\
October & Maximum & 22.11 & 0.751 & 3.4 \\
\multirow{2}{*}{ November } & Maximum & 33.95 & 0.881 & 2.6 \\
\multirow{2}{*}{ December } & Maximum & 22.23 & 0.512 & 2.3 \\
& Maximum & 36.44 & 0.731 & 2.0 \\
& Maximum & 21.57 & 0.892 & 4.1 \\
& Maximum & 34.37 & 1.415 & 4.1 \\
& Maximum & 17.70 & 1.06 & 6.0 \\
& Maximum & 31.66 & 1.620 & 5.3 \\
& & 14.56 & 1.173 & 8.1 \\
\hline
\end{tabular}

Table 2. Monthly temperature variation in Potikum (1956-2015)

\begin{tabular}{lllll}
\hline Month & Temperature & Mean $\left({ }^{\circ} \mathbf{C}\right)$ & Std. Deviation $\left({ }^{\circ} \mathbf{C}\right)$ & $\mathbf{C . V}\left({ }^{\circ} \mathbf{C}\right)$ \\
\hline January & Maximum & 30.83 & 1.529 & 4.9 \\
& Minimum & 13.39 & 1.031 & 7.7 \\
February & Maximum & 33.67 & 1.776 & 5.8 \\
& Minimum & 16.39 & 1.379 & 8.4 \\
March & Maximum & 37.19 & 1.318 & 3.5 \\
& Minimum & 20.64 & 1.214 & 5.9 \\
April & Maximum & 38.59 & 0.965 & 2.5 \\
& Minimum & 23.98 & 0.971 & 4.1 \\
May & Maximum & 37.91 & 0.893 & 2.4 \\
& Minimum & 24.58 & 0.906 & 3.7 \\
June & Maximum & 35.51 & 0.976 & 2.7 \\
& Minimum & 23.68 & 0.762 & 3.2 \\
July & Maximum & 32.37 & 1.121 & 3.5 \\
& Minimum & 22.03 & 0.786 & 3.6 \\
August & Maximum & 30.89 & 1.162 & 3.8 \\
& Minimum & 21.43 & 0.733 & 3.4 \\
September & Maximum & 32.59 & 0,797 & 2.4 \\
& Minimum & 21.46 & 0.505 & 2.4 \\
October & Maximum & 35.22 & 0.708 & 2.0 \\
\multirow{2}{*}{ November } & Minimum & 20.79 & 0.837 & 4.0 \\
& Maximum & 39.92 & 1.289 & 3.8 \\
December & Minimum & 17.09 & 1.145 & 6.7 \\
& Maximum & 31.62 & 1.504 & 4.8 \\
& Minimum & 14.27 & 1.216 & 8.5 \\
\hline
\end{tabular}


the temperature in Yobe in March was warmer by $0.1^{\circ} \mathrm{C}$ to $3.6^{\circ} \mathrm{C}$ than normal; that of April was warmer by $0.1^{\circ} \mathrm{C}$ to $1.9^{\circ} \mathrm{C}$ (Fig. 7). The May temperature was warmer by between $0.1^{\circ} \mathrm{C}$ and $2.2^{\circ} \mathrm{C}$. On the contrary, the temperature of January, February and December were cooler than normal by values between $-0.1^{\circ} \mathrm{C}$ and $5.2^{\circ} \mathrm{C} ;-0.1^{\circ} \mathrm{C}$ and $-4.1^{\circ} \mathrm{C} ;-0.1^{\circ} \mathrm{C}$ and $-3.5^{\circ} \mathrm{C}$ respectively. It is obvious from Fig. 4, Fig. 5 and Fig. 15 that the maximum and minimum temperatures for January, February and December respectively showed downward trends while the temperatures of other months March to November (Figs. 6-14) showed upward trends. It means the temperatures of January, February and December were cooler than normal within the period while that of March to November were warmer than normal during the period (19562015). The downward negative trends in temperature in January, February and December might be attributed to the influence of harmattan wind in the area.

Other months such as June, July and August experienced warmer than normal, which ranges from $0.1^{\circ} \mathrm{C}$ to $3.5^{\circ} \mathrm{C}$. The months of September, October and November were also warmer than normal by between $0.1^{\circ} \mathrm{C}$ to $2.5^{\circ} \mathrm{C}$. This implies that the temperatures of these months are warmer in most cases to the extent of being detrimental to the heath of people in the study area and other natural phenomenon.

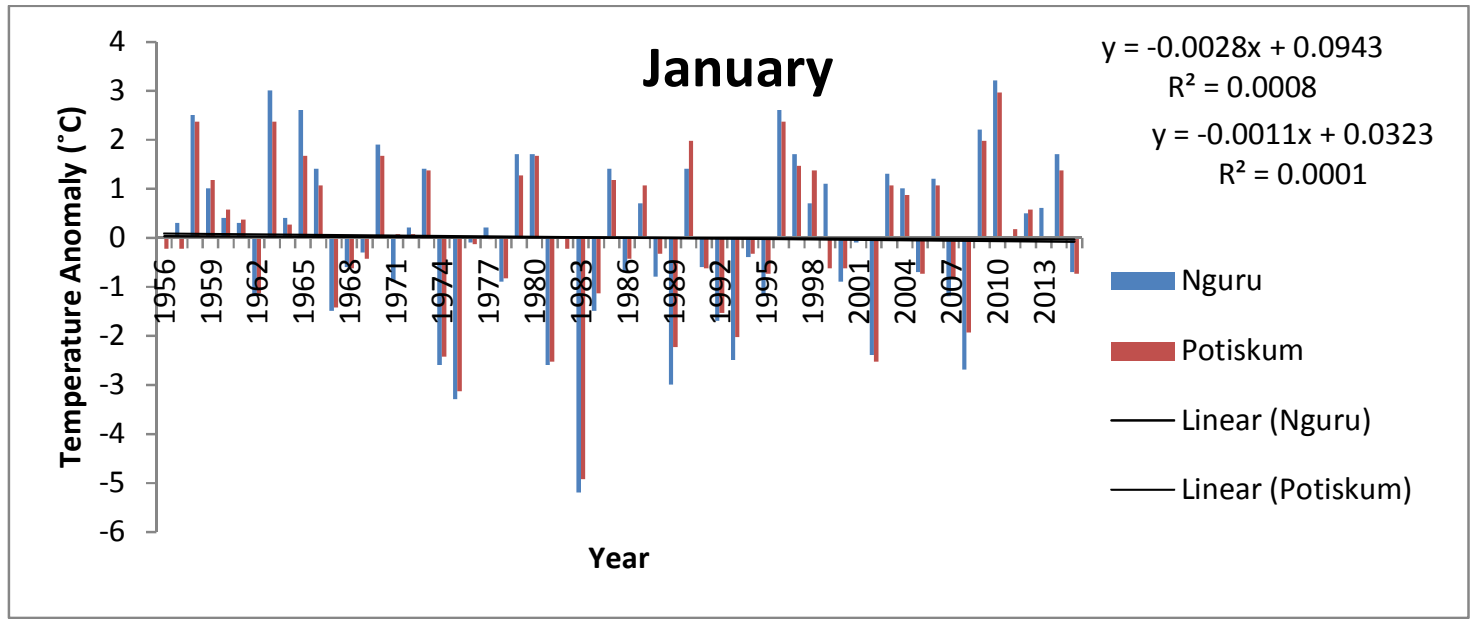

Fig. 4. Trends in mean temperature anomalies for the month of January in Yobe (1956-2015) Source: Authors' Fieldwork, 2021

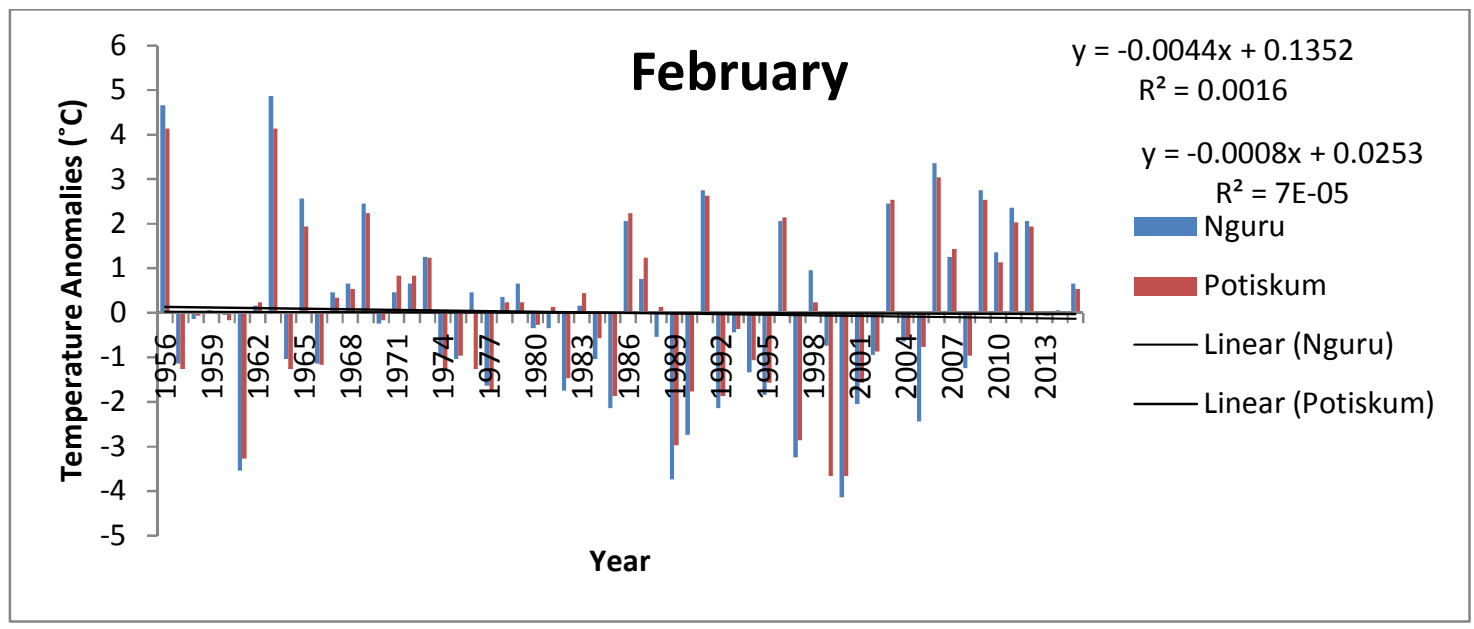

Fig. 5. Trends in mean temperature anomalies for the month of February in Yobe (1956-2015) Source: Authors' Fieldwork, 2021 


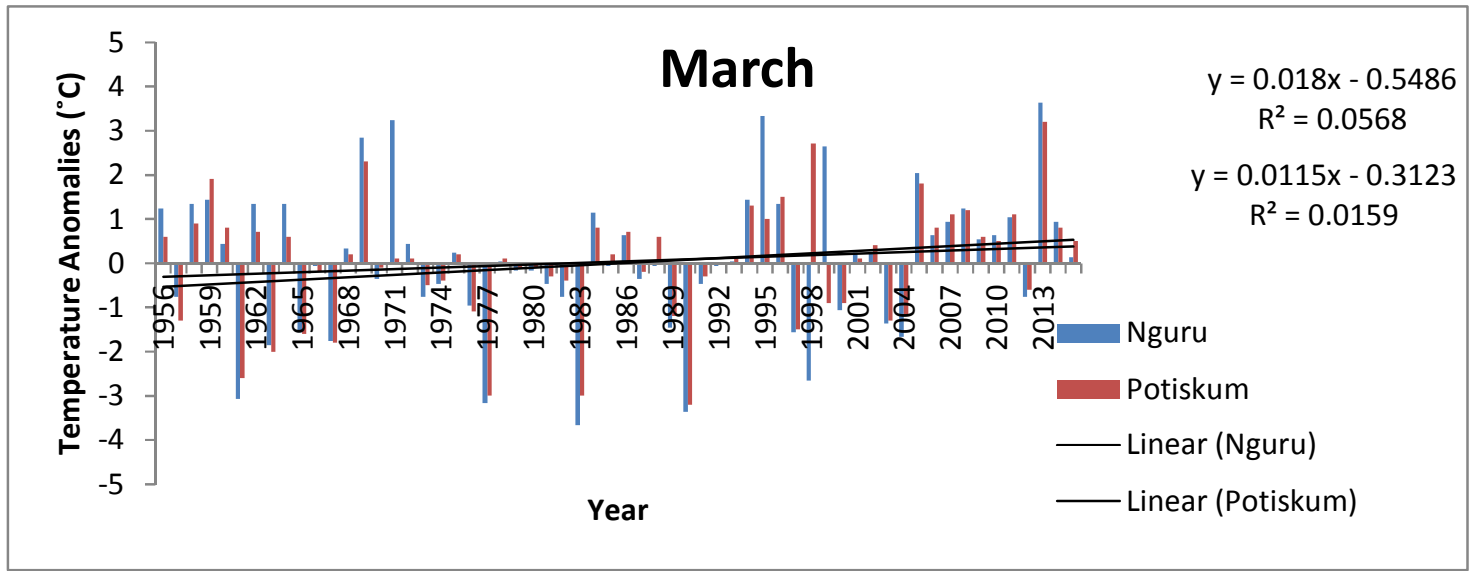

Fig. 6. Trends in mean temperature anomalies for the month of March in Yobe (1956-2015) Source: Authors' Fieldwork, 2021

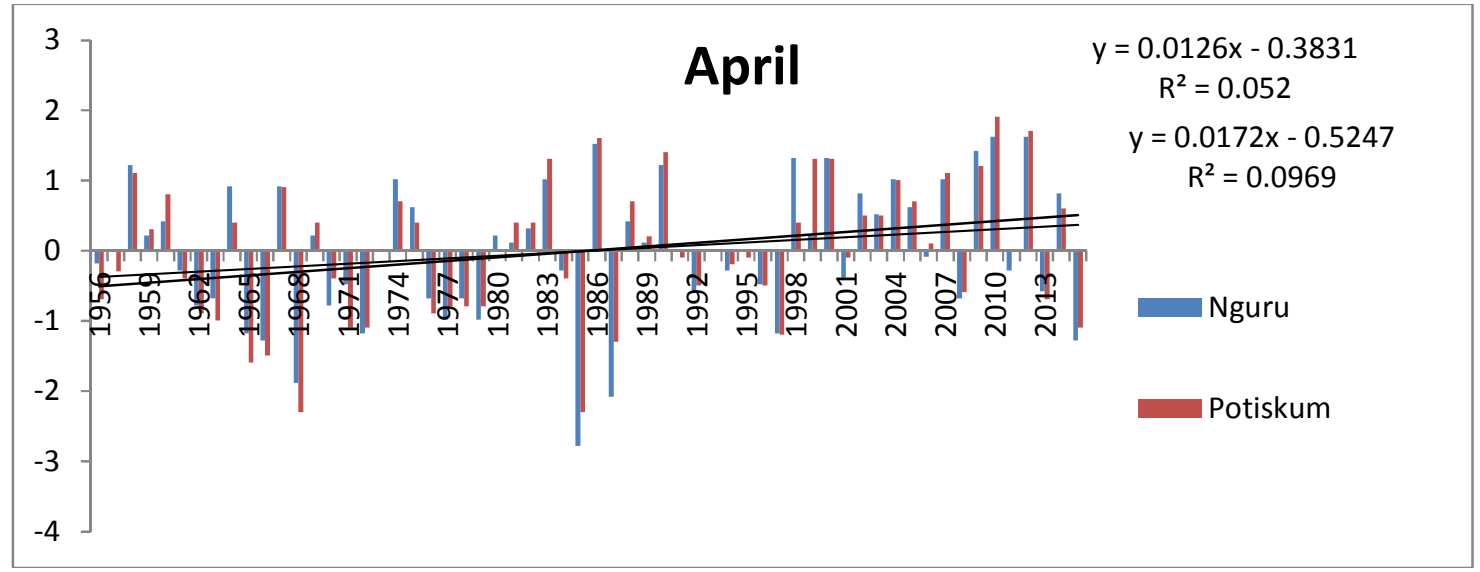

Fig. 7. Trends in mean temperature anomalies for the month of April in Yobe (1956-2015) Source: Authors' Fieldwork, 2021

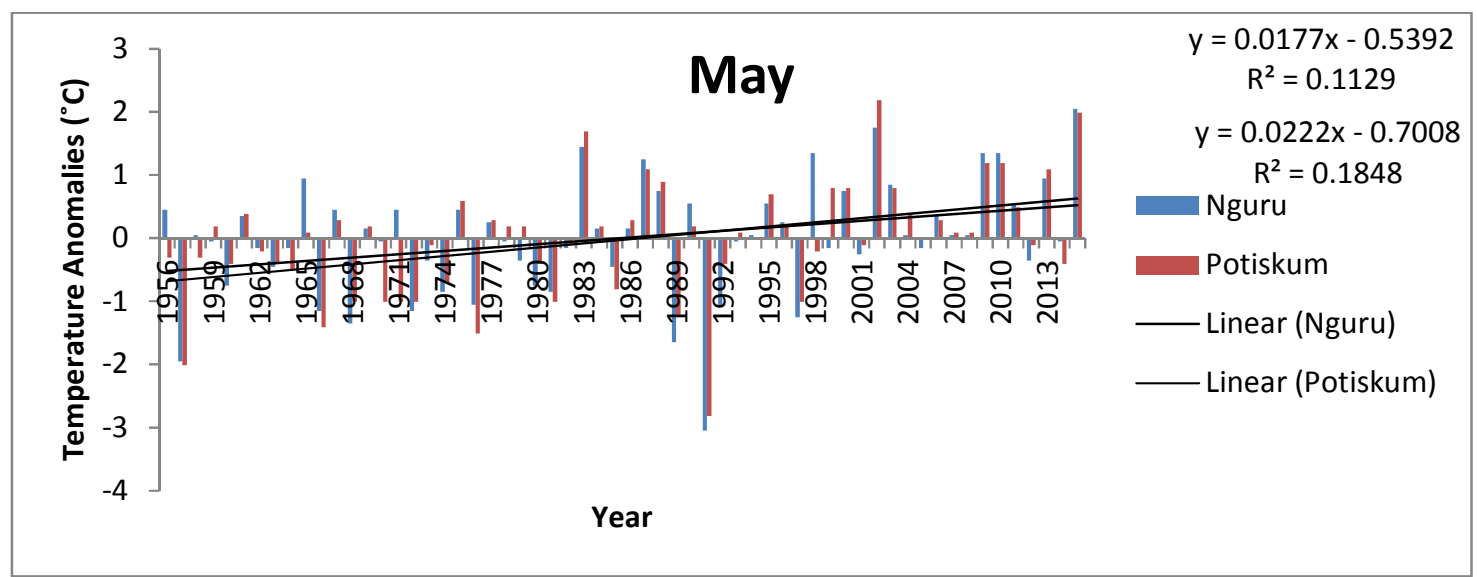

Fig. 8. Trends in mean temperature anomalies for the month of May in Yobe (1956-2015) Source: Authors' Fieldwork, 2021 


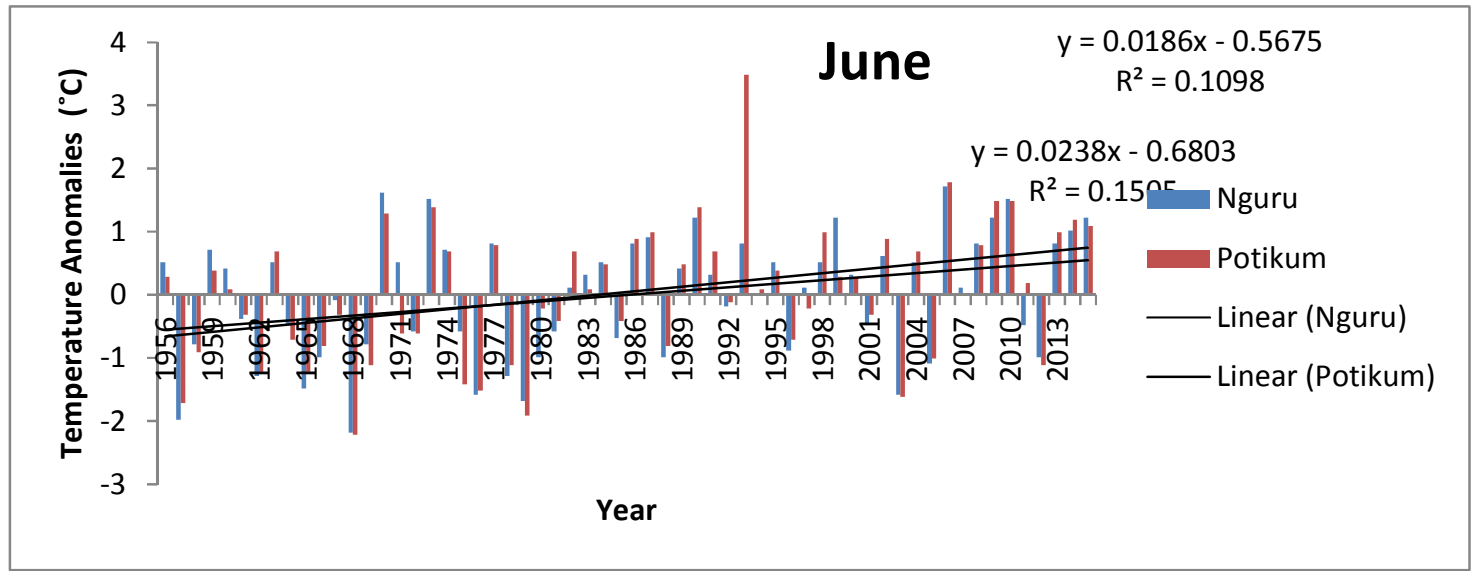

Fig. 9. Trends in mean temperature anomalies for the month of June in Yobe (1956-2015) Source: Authors' Fieldwork, 2021

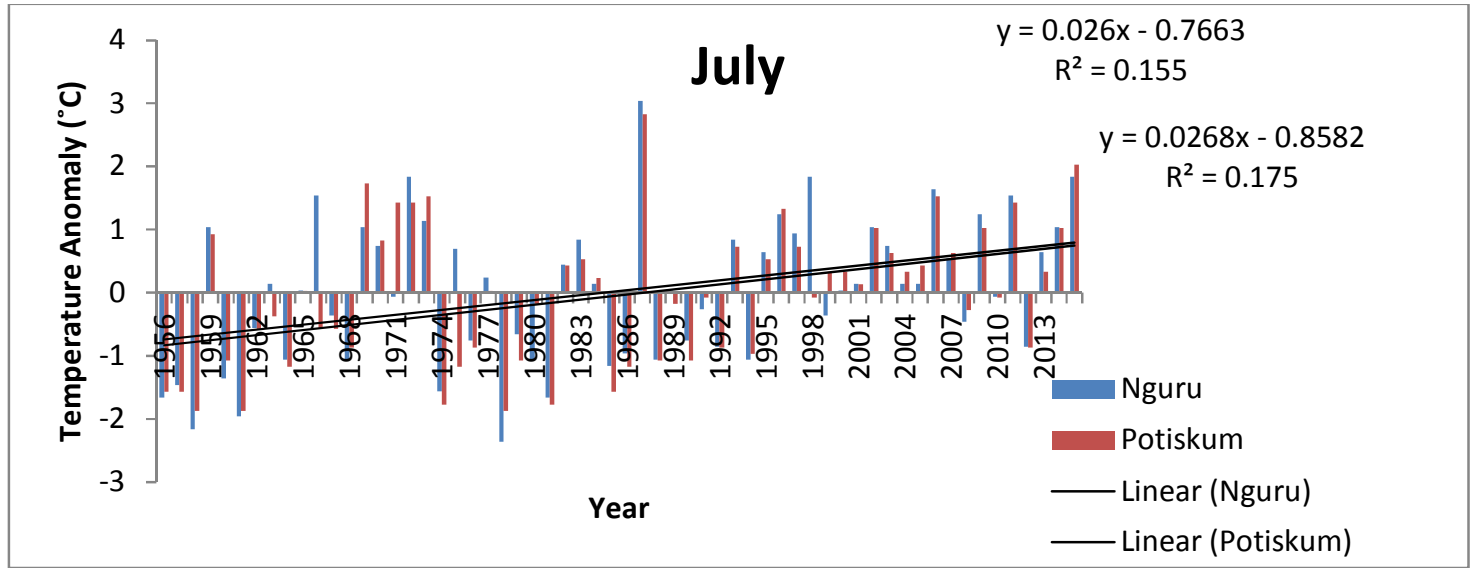

Fig. 10. Trends in mean temperature anomalies for the month of July in Yobe (1956-2015) Source: Authors' Fieldwork, 2021

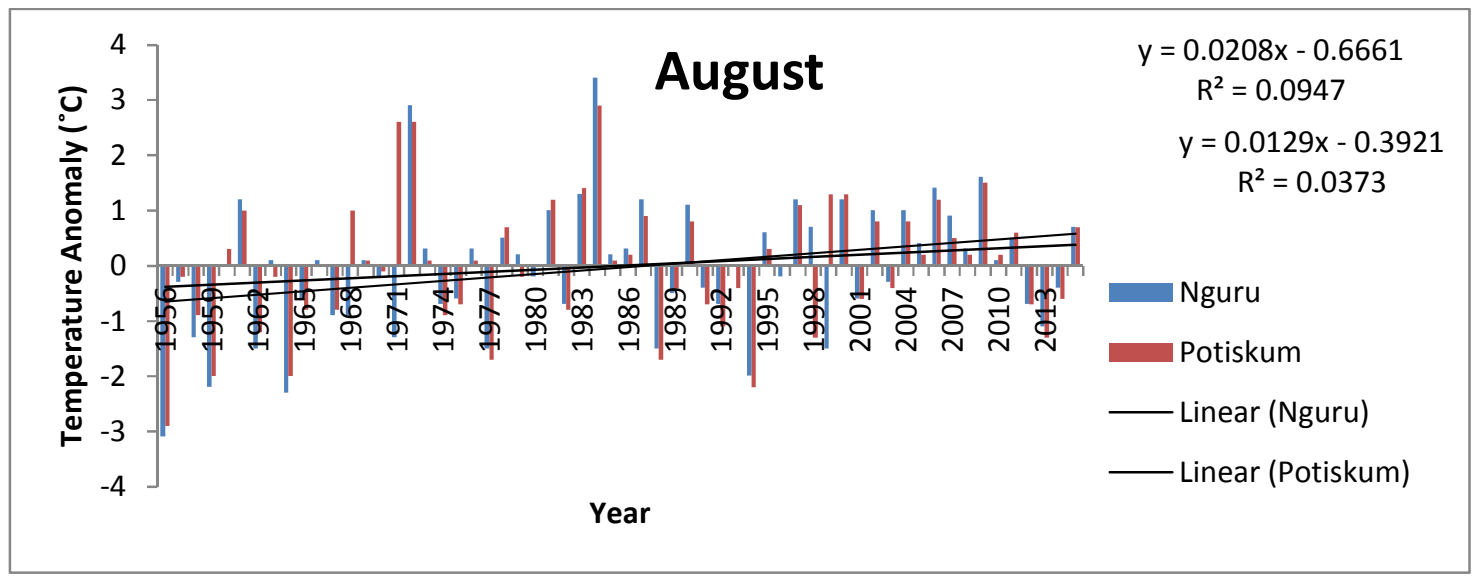

Fig. 11. Trends in mean temperature anomalies for the month of August in Yobe (1956-2015) Source: Authors' Fieldwork, 2021 


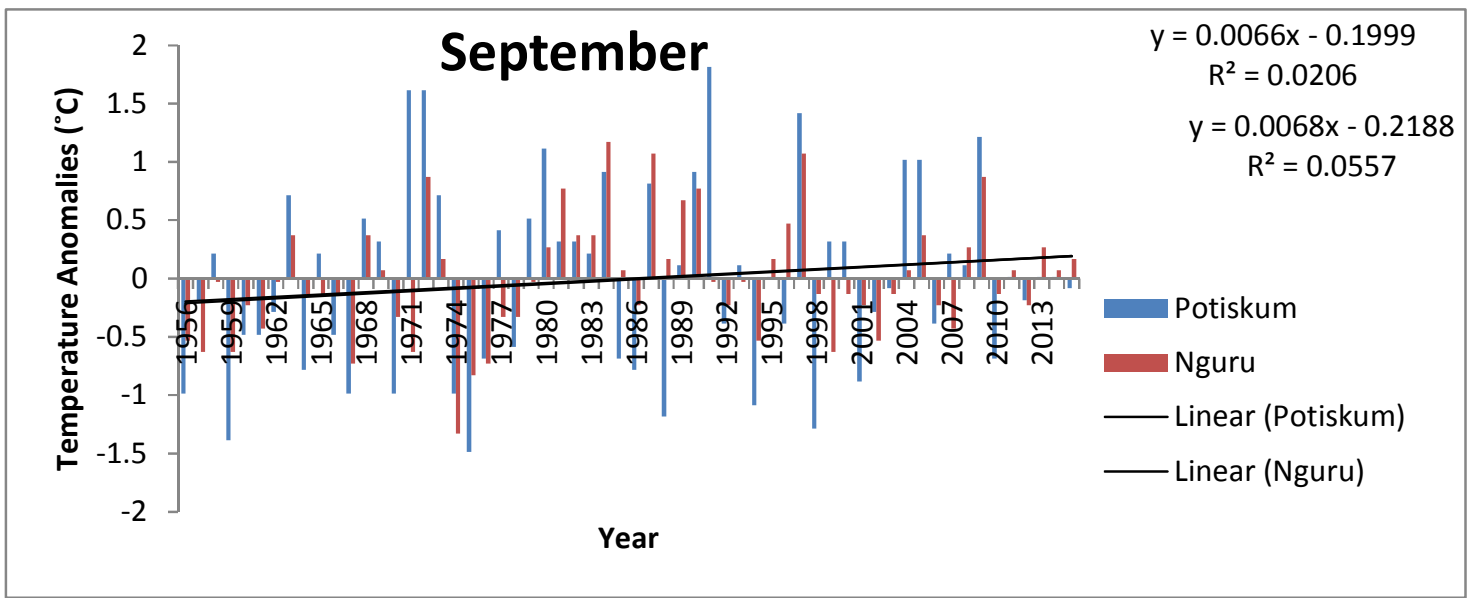

Fig. 12. Trend in mean temperature anomalies for the month of September in Yobe (1956-2015) Source: Authors' Fieldwork, 2021

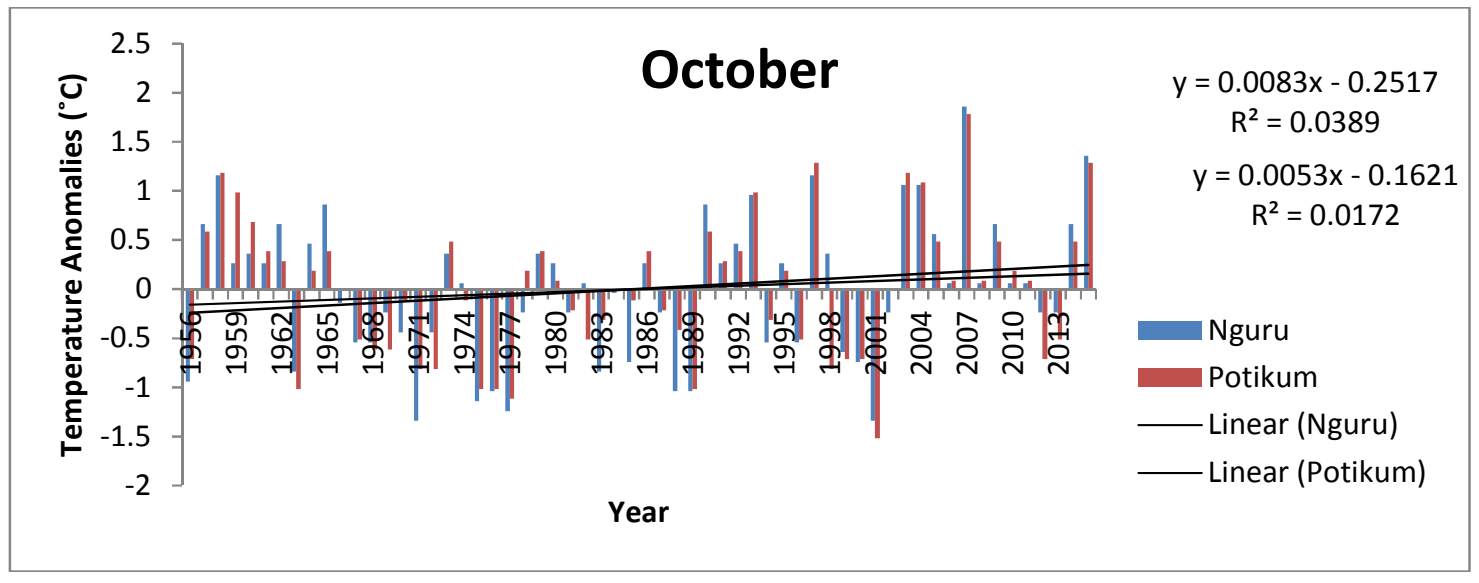

Fig. 13. Trends in mean temperature anomalies for the month of October in Yobe (1956-2015) Source: Authors' Fieldwork, 2021

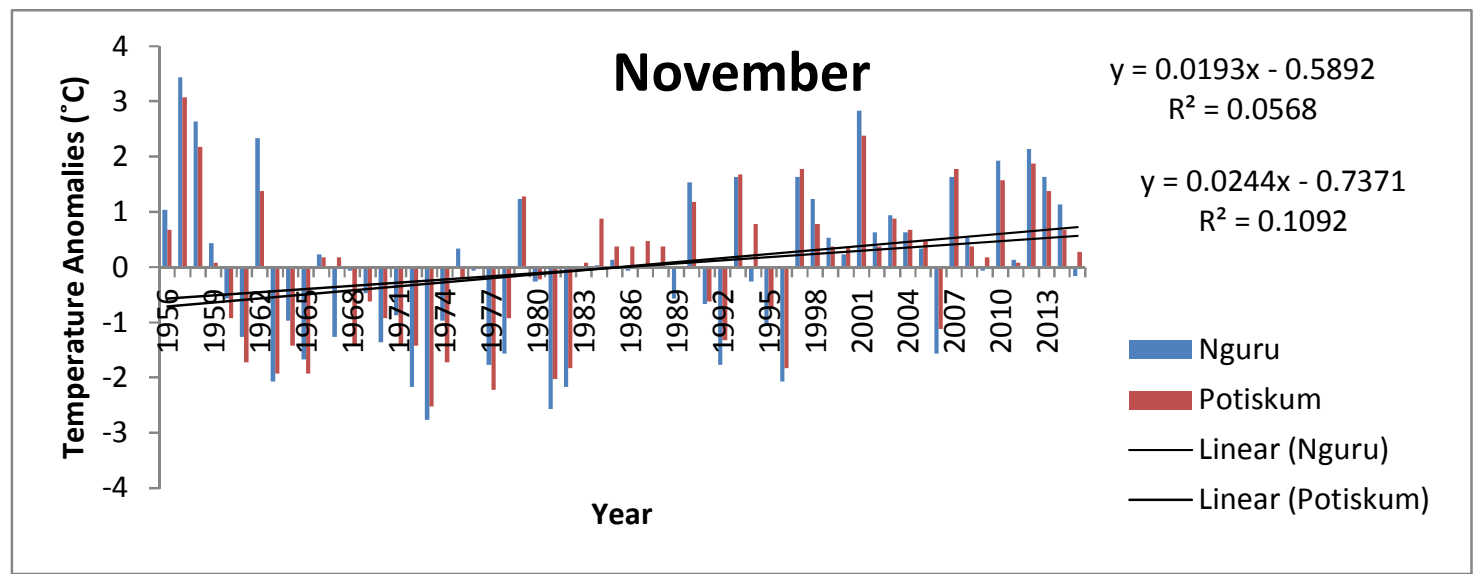

Fig. 14. Trends in mean temperature anomalies for the month of November in Yobe (1956-2015) Source: Authors' Fieldwork, 2021 


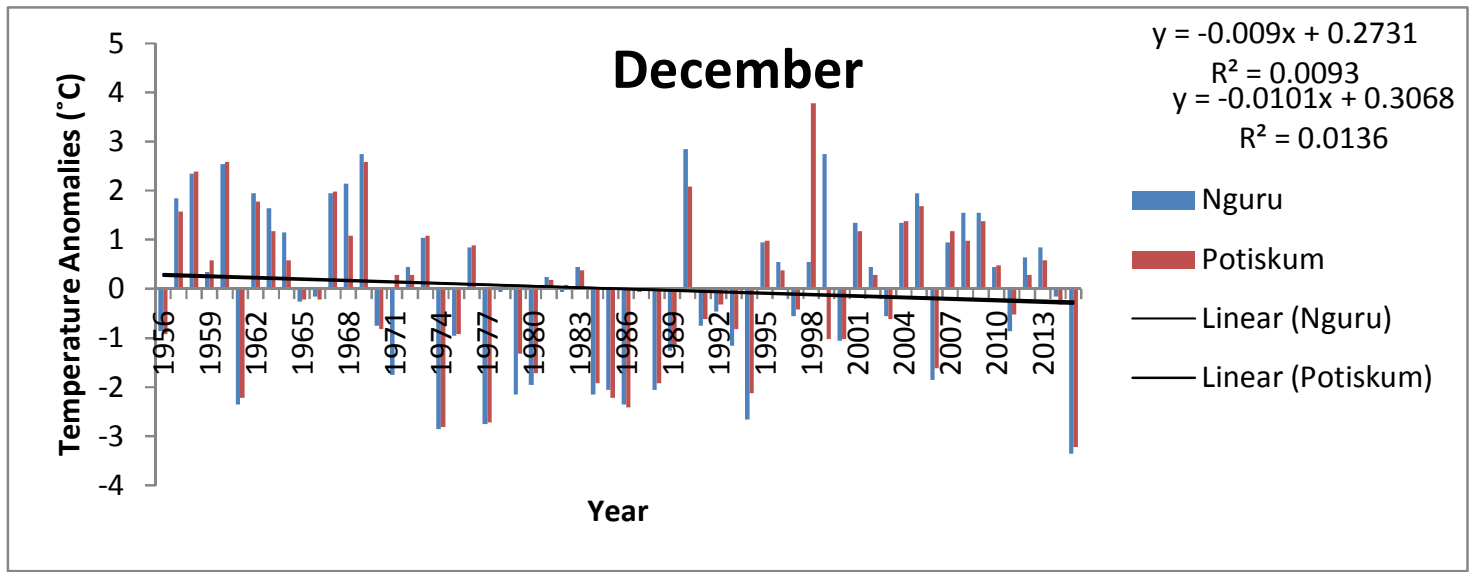

Fig. 15. Trends in mean temperature anomalies for the month of December in Yobe (1956-2015) Source: Authors' Fieldwork, 2021

Table 3. Descriptive statistics on the annual temperature for Yobe (1956-2015)

\begin{tabular}{|c|c|c|c|c|c|c|c|}
\hline Variable & $\mathbf{N}$ & $\begin{array}{l}\text { Range } \\
\left({ }^{\circ} \mathrm{C}\right)\end{array}$ & $\begin{array}{l}\text { Minimum } \\
\left({ }^{\circ} \mathrm{C}\right)\end{array}$ & $\begin{array}{l}\text { Maximum } \\
\left({ }^{\circ} \mathrm{C}\right)\end{array}$ & $\begin{array}{l}\text { Mean } \\
\left({ }^{\circ} \mathrm{C}\right)\end{array}$ & $\operatorname{Std}\left({ }^{\circ} \mathrm{C}\right)$ & $\begin{array}{l}\text { Variance } \\
\left({ }^{\circ} \mathrm{C}\right)\end{array}$ \\
\hline \multicolumn{8}{|l|}{ Nguru Station } \\
\hline Maximum Temperature & 60 & 2.4 & 34.00 & 36.35 & 35.02 & 0.497 & 0.247 \\
\hline $\begin{array}{l}\text { Minimum Temperature } \\
\text { Potiskum Station }\end{array}$ & 60 & 2.1 & 19.61 & 21.73 & 20.5 & 0.514 & 0.264 \\
\hline Maximum Temperature & 60 & 2.2 & 33.21 & 35.43 & 34.2 & 0.480 & 0.231 \\
\hline Minimum Temperature & 60 & 2.3 & 18.95 & 21.26 & 19.9 & 0.534 & 0.285 \\
\hline
\end{tabular}

This finding is in agreement with the NIMET's Quarterly Weather Review (2013) [22] which reports that the maximum temperature departures in most parts of the country including Yobe State were higher than normal conditions. It further stressed that the generally higher than normal maximum temperatures in January is a good indicator of a less than normal harmattan in the month. NIMET's Quarterly Weather Review (2013) [22] also stated that the minimum temperature for January was warmer than normal due to the less than normal harmattan in most part of the northern part of Nigeria. Further finding of NIMET's February and March departures of observed maximum temperatures were warmer than normal across Nigeria ranging from $0.5^{\circ} \mathrm{C}$ to $3.0^{\circ} \mathrm{C}$. These temperature anomalies continued in other months of the year and it is a strong indication of Climate Change and very weather condition. This finding conforms to the findings of the NIMET's Agrometeorological Bulletin (April-June, 2012) [23], which reports that the extreme northern parts of the country had warmer than normal temperatures in April. It further stressed that the actual mean maximum temperature distribution revealed that places like Bauchi, Gusau, Kano, Katsina, Nguru, Potiskum, Sokoto and Yola recorded not less than $40^{\circ} \mathrm{C}$ during the first decade. According to the NIMET's Bulletin (2012) [23] the mean maximum temperature anomalies in most part of Nigeria are warmer than normal in May. The same anomaly applied to June in the extreme northern parts of the country and the temperature was warmer by above $2.5^{\circ} \mathrm{C}$ in April to June.

\subsection{Annual Temperature and Its Changing Pattern in Yobe}

The result in Table 3 showed that the annual long-term mean of maximum and minimum temperatures in Nguru are $35.02^{\circ} \mathrm{C}$ and $20.5^{\circ} \mathrm{C}$ respectively. The result in the table also showed that the mean annual long-term maximum and minimum temperatures for Potiskum are $34.2^{\circ} \mathrm{C}$ and $19.8^{\circ} \mathrm{C}$ respectively. The mean annual temperature at the two stations indicates a very hot condition in Yobe State, which could leads to health challenges such as heatstroke, health exhaustion, muscle cramps, heat swelling [20]. The table shows that the annual range of 
maximum temperature and minimum temperatures for Nguru are $2.4^{\circ} \mathrm{C}$ and $2.1^{\circ} \mathrm{C}$ respectively while that of Potiskum are $2.2^{\circ} \mathrm{C}$ and $2.3^{\circ} \mathrm{C}$ respectively. Table 3 further revealed that the standard deviations for maximum and minimum temperatures in Nguru are 0.497 and 0.514 respectively, which indicates variations in the annual temperatures in the area. It is also evident from the table that the standard deviations for maximum and minimum temperatures in Potiskum are 0.480 and 0.534 respectively. This also indicates variations in the mean annual temperatures in the area.

This implies that there is a wider gap between the highest annual maximum and the lowest maximum temperature likewise, the highest minimum annual temperature and lowest annual minimum temperature in Yobe State. This equally indicates significant changes in the annual temperatures over the long-term period in the area. This finding is in agreement with the finding of Hassan et al. [15] which examined the trends rainfall and temperature over northeastern Nigeria between 1949 and 2014 and found that the mean annual temperature for Nguru and Potiskum were $29^{\circ} \mathrm{C}$ and $28^{\circ} \mathrm{C}$ respectively. The study also revealed that the standard deviation for Nguru and Potiskum were 0.64 and 0.65 respectively.

The result in Fig. 16 showed that the year 2009 recorded the highest mean annual maximum temperature of $36.4^{\circ} \mathrm{C}$ while the lowest mean annual maximum temperature of $34.0^{\circ} \mathrm{C}$ was recorded in the year 1989 in Nguru. Further analysis in Fig. 16 revealed that the year 1998 recorded the highest mean annual minimum temperature of $21.6^{\circ} \mathrm{C}$ in Nguru Station and the lowest mean annual minimum temperature of $19.4^{\circ} \mathrm{C}$ in the year 2001 .

The result in Fig. 17 revealed that the year 2009 recorded the highest mean annual maximum temperature of $36.4^{\circ} \mathrm{C}$ and lowest mean annual maximum temperature of $33.2^{\circ} \mathrm{C}$ in the year 1977 in Potiskum. This indicates that the year 2009 is the hottest year in Potikum and 1977 was the coldest year. The figure also showed that the year 2010 recorded the highest mean annual minimum temperature of $21.3^{\circ} \mathrm{C}$ in Potiskum and the lowest of $18.97^{\circ} \mathrm{C}$ in 1957 . This implies that the year 2009 was the hottest year and the year 1989 was the coldest year during the period (1956-2015) in Yobe State.

It is obvious that the years 2000 to 2009 were hotter than any other decade during the period as all the years recorded mean annual temperatures above $35^{\circ} \mathrm{C}$. This finding in line with the assertion made by Denchak [5] that the years 2000 to 2009 were hotter than any other decade in the past 1,300 years. This finding is in tandem with the finding of Yusuf et al. [16] that concludes that in general term, the temperature were observed to be higher in the northern parts of Nigeria as result of its proximity to the Sahara desert, which has less cloud cover and is therefore more exposed to solar radiation.

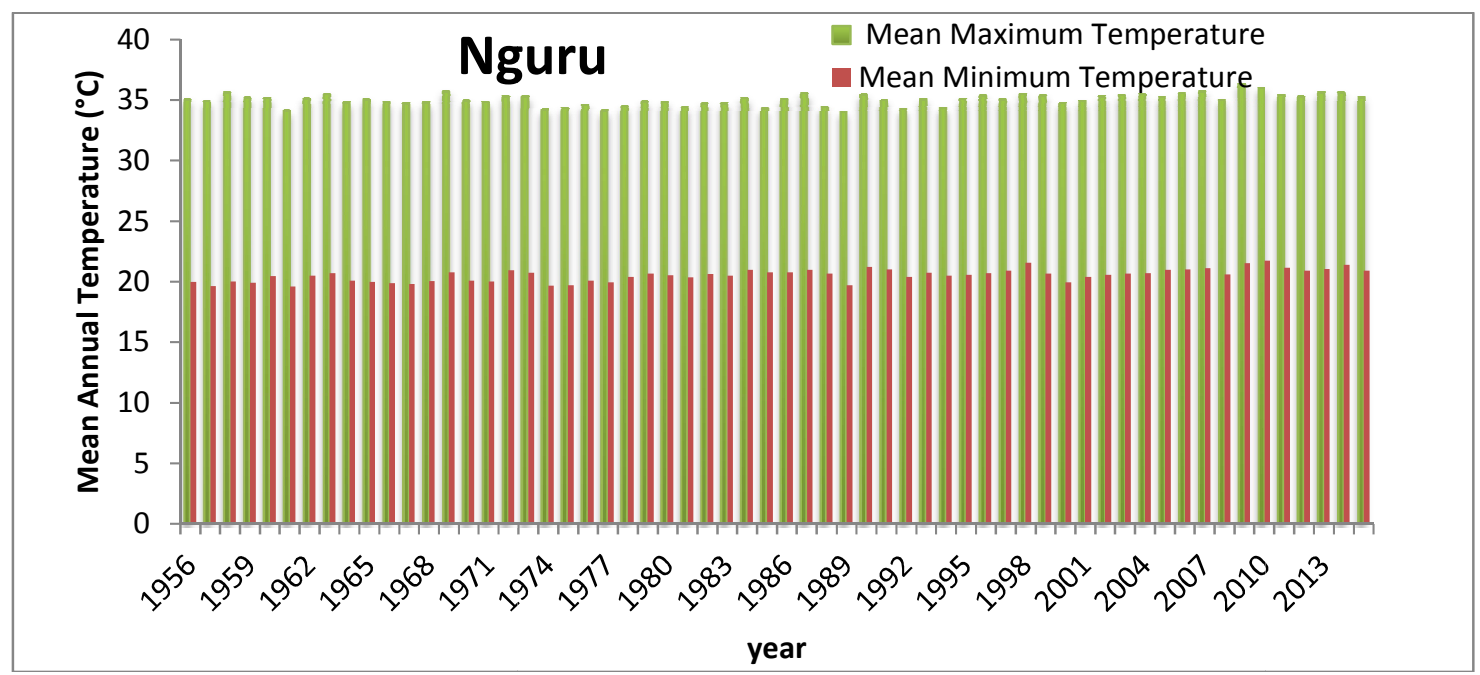

Fig. 16. Inter-annual mean maximum and minimum temperature variability in Nguru (1956-2015)

Source: Authors' Fieldwork, 2021 


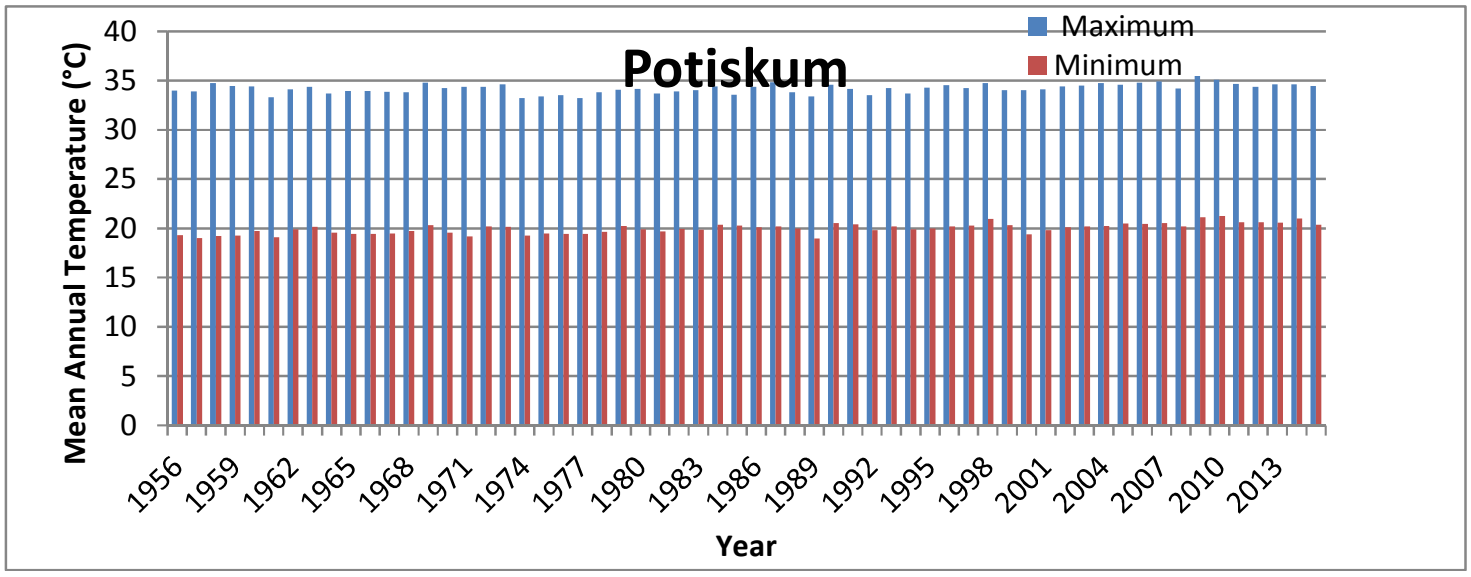

Fig. 17. Inter-annual mean maximum and minimum temperature variability in Potiskum (1956-2015)

Source: Authors' Fieldwork, 2021

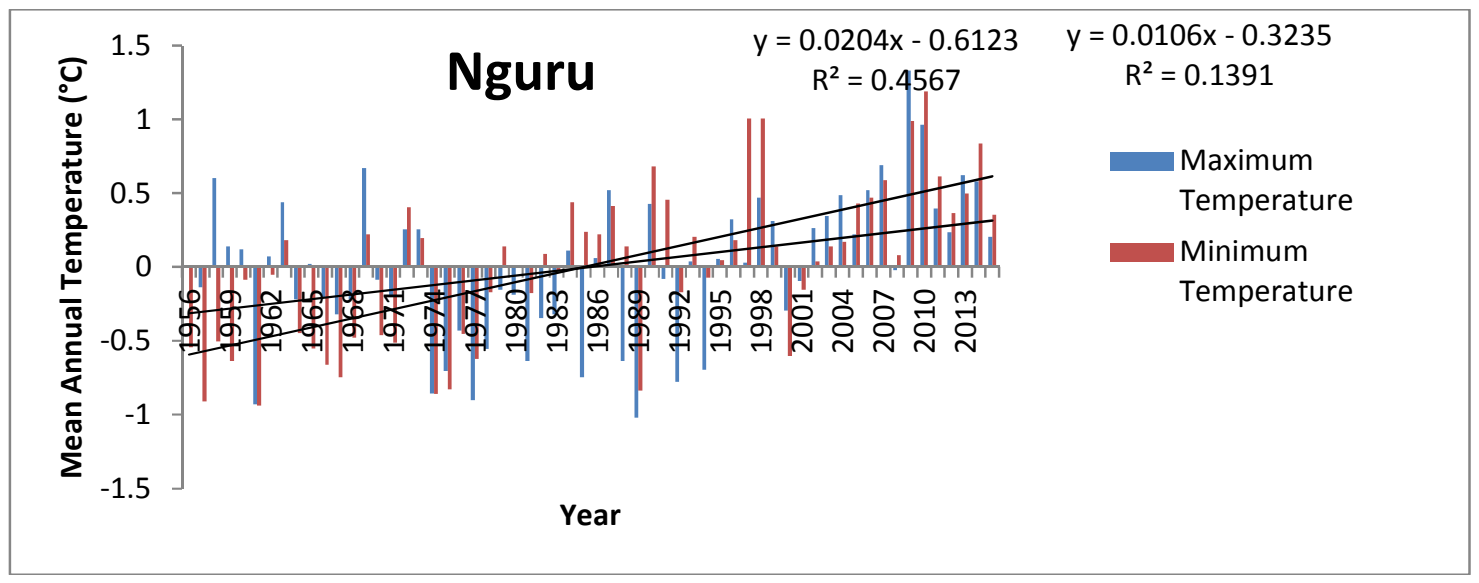

Fig. 18. Trends in mean annual temperature anomaly for Nguru (1956-2015) Source: Authors' Fieldwork, 2021

\subsection{Annual Temperature Anomaly in Yobe}

It could be observed from Fig. 18 that $64.3 \%$ between1956-1983 witnessed negative anomalies in their annual maximum temperatures while $71.9 \%$ of the years among the years 1984-2015 witnessed positive anomaly in Nguru. In addition, $78.6 \%$ of the years between 1956 and 1983 in Nguru recorded negative anomaly in their minimum temperatures while $84.1 \%$ of the years between 1984 and 2015 recoded positive anomaly in their minimum temperatures. This indicates that Nguru recorded a relatively low maximum temperature below the long-term mean of $35.02^{\circ} \mathrm{C}$ during the period while the period 1984 to 2015 recorded high temperature above the long-term mean. Fig. 18 revealed upward trends in maximum and minimum temperatures by $0.10^{\circ} \mathrm{C}-0.202^{\circ} \mathrm{C}$ over the period (1956-2015), which is an indication of warmer condition than normal in Nguru.

Similarly, the result in Fig. 19 revealed that $71.1 \%$ of the years between 1956 and 1983 experienced negative anomaly in their maximum temperature in Potiskum while $74.2 \%$ of the years between 1984 and 2015 recorded positive anomaly in maximum temperature. It could also be observed from Fig. 19 that $67.9 \%$ of the years between 1956 and 1983 in Potiskum recorded negative anomaly while $81.3 \%$ recorded positive anomaly between 1984 and 2015 in Potiskum. This implies that the period (1956 to 1983) recorded a relatively low maximum and low minimum temperature below the long-term mean of $34.2^{\circ} \mathrm{C}$ while it recorded high temperature above the long-term mean between 1984 and 
2015 in the area. This further implies that the temperature of Yobe State was generally higher between 1984 and 2015 compared to the period between 1956 and 1983.

This finding is in tandem with the finding of the Odjugo [11] which stated that the temperature increased by $2.0^{\circ} \mathrm{C}$ in Nguru, semi-arid city of Nigeria between 1901 and 2005. This finding also corroborates to the report of the IPCC [3] which reported that the global temperatures have increased by $0.4-0.8^{\circ} \mathrm{C}$ with a mean of $0.74^{\circ} \mathrm{C}$ since 1960 and it is projected to increase between $1,6-4.5^{\circ} \mathrm{C}$ by the year 2100 . This finding is in tandem with the finding of Abdussalam [24] which examined change in indices of daily temperature and rainfall extremes for period 1971-2010 and found that there has been significant increase in days that are warm and significant decrease in the days that are cold in the northeastern Nigeria.

\subsection{Decadal Changes in Temperature over Yobe}

The result in Table 4 showed that the temperature of in Nguru was increasing at the rate of $2.1^{\circ} \mathrm{C}$ per decade during the period (1956-2015) while it was increasing at the rate of $2.2^{\circ} \mathrm{C}$ per decade in Potiskum during the period under review. From the foregoing, it means the temperature of Yobe State was increasing at the rate of $2.1^{\circ} \mathrm{C}$ per decade and this implies an increase in hot condition in condition.

The result in Table 4 shows that the maximum temperature in Nguru has the highest coefficient of variation (C.V) (1.6\%) during the decade (1986-1995) while the decade (1996-2005) has the lowest C.V of $0.98 \%$. Similarly, Table 3 reveals that the maximum temperature in Potiskum has the highest C.V of $1.5 \%$ during the decade (1966-1975) while the decade (1996$2005)$ has the lowest C.V (0.8\%) of maximum temperature during the decade (1996-2005). This also indicates that the temperature in Potiskum was highly variable between 1966 and 1975 and less stable during the period in Potiskum. This further implies that in general term; the temperature was more variable in Yobe between the decade (1986 and 1995) and less variable between 1996 and 2005 in the State.

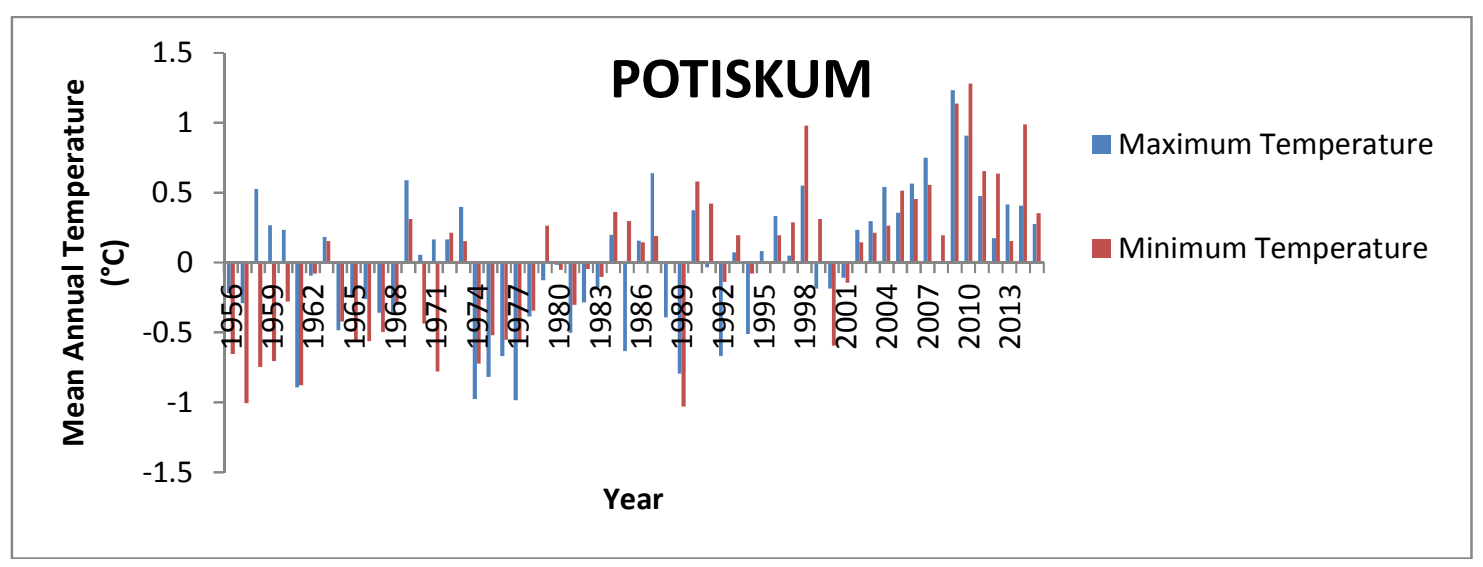

Fig. 19. Mean annual temperature anomaly for Potiskum (1956-2015) Source: Authors' Fieldwork, 2021

Table 4. Decadal changes in maximum temperature in Yobe (1956-2015)

\begin{tabular}{|c|c|c|c|c|}
\hline \multirow[b]{2}{*}{ Decade } & \multicolumn{2}{|c|}{ Nguru } & \multicolumn{2}{|c|}{ Potiskum } \\
\hline & $\begin{array}{l}\text { Decadal } \\
\text { mean }\left({ }^{\circ} \mathrm{C}\right)\end{array}$ & $\begin{array}{l}\text { Decadal } \\
\text { Changes }\left({ }^{\circ} \mathrm{C}\right)\end{array}$ & Decadal mean $\left({ }^{\circ} \mathrm{C}\right)$ & $\begin{array}{l}\text { Decadal Changes } \\
\left({ }^{\circ} \mathrm{C}\right)\end{array}$ \\
\hline 1956-1965 & 35.03 & 0.011528 & 34.09 & -0.10277778 \\
\hline $1966-1975$ & 34.88 & -0.14097 & 34.05 & -0.14111111 \\
\hline 1976-1985 & 34.60 & -0.41681 & 33.84 & -0.35777778 \\
\hline 1986-1995 & 34.81 & -0.21097 & 34.09 & -0.10694444 \\
\hline $1996-2005$ & 35.23 & 0.205694 & 34.38 & 0.188055556 \\
\hline 2006-2015 & 35.57 & 0.551527778 & 34.71 & 0.520555556 \\
\hline Total & & 2.13163 & & 2.16493 \\
\hline
\end{tabular}

Source: Authors' Fieldwork, 2021 
Table 5. Coefficient of variation of temperature over Yobe (1956-2015)

\begin{tabular}{lllllll}
\hline Decade & \multicolumn{3}{c}{ Nguru } & \multicolumn{3}{c}{ Potiskum } \\
\cline { 2 - 7 } & $\begin{array}{l}\text { Decadal } \\
\text { mean }\left({ }^{\circ} \mathbf{C}\right)\end{array}$ & $\begin{array}{l}\text { Stad. } \\
\text { Deviation }\left({ }^{\circ} \mathbf{C}\right)\end{array}$ & $\mathbf{C . V}(\%)$ & $\begin{array}{l}\text { Decadal mean } \\
\left({ }^{\circ} \mathbf{C}\right)\end{array}$ & $\begin{array}{l}\text { Stad. Deviation } \\
\left({ }^{\circ} \mathbf{C}\right)\end{array}$ & \\
\hline $1956-1965$ & 35.03 & 0.41166 & 1.2 & 34.09 & 0.416 & 1.22 \\
$1966-1975$ & 34.88 & 0.45286 & 1.3 & 34.05 & 0.508 & 1.5 \\
$1976-1985$ & 34.60 & 0.30359 & 0.98 & 33.84 & 0.350 & 1.03 \\
$1986-1995$ & 34.81 & 0.53388 & $\mathbf{1 . 6}$ & 34.09 & 0.467 & 1.4 \\
$1996-2005$ & 35.23 & 0.25190 & $\mathbf{0 . 7}$ & 34.38 & 0.279 & $\mathbf{0 . 8}$ \\
$2006-2015$ & 35.57 & 0.39012 & 1.04 & 34.71 & 0.362 & 1.04 \\
\hline \multicolumn{3}{c}{ Source: Authors' Fieldwork, 2021 }
\end{tabular}
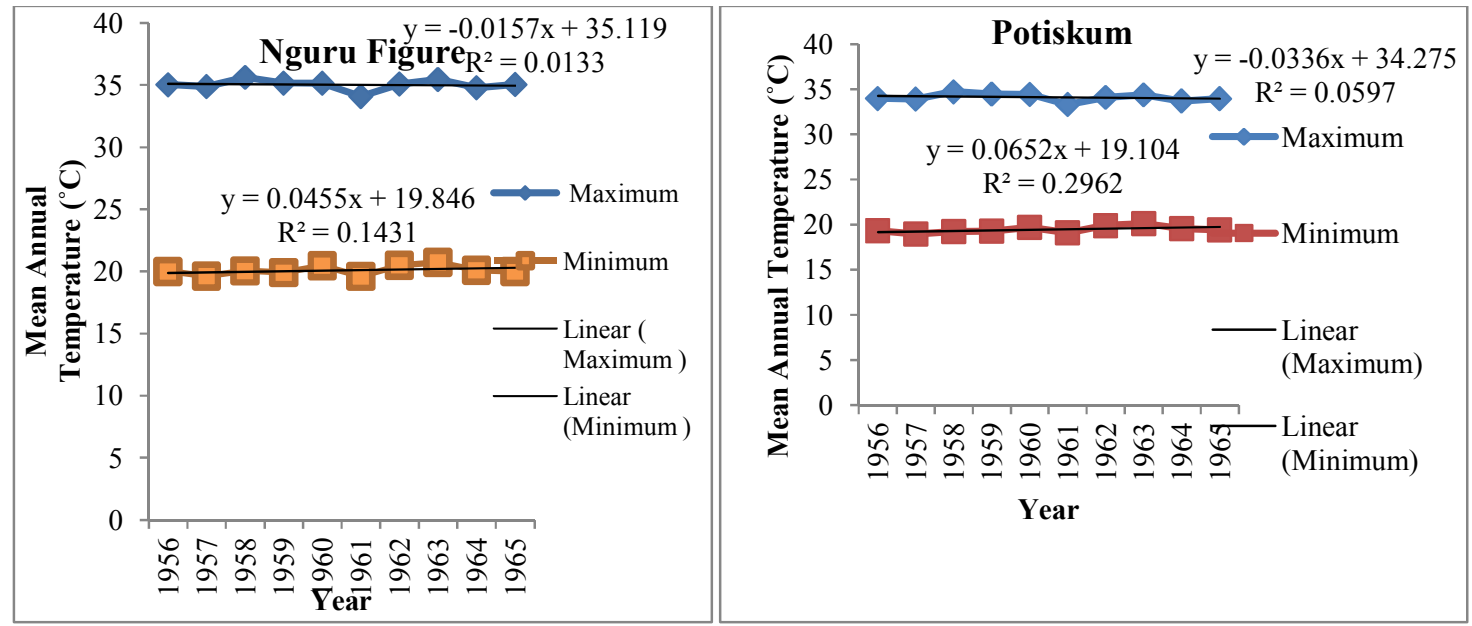

Fig. 20. Temperature trend in Yobe (1956-1965)

Source: Authors' Fieldwork, 2021

This results is in conformity with the finding of Yusuf et al. [16] which found that temperature varies seasonally in Nigeria and that the variations were observed with higher values in the north, which is arid in nature. The study of Yusuf et al. [16] concluded that there is a continuous variability that is seasonally dependent in each year. The maximum temperature in north eastern Nigeria is $43.1^{\circ} \mathrm{C}$; the maximum temperature observed in Yola (Northeastern Nigeria) 1s 3.1\% above that of the NIMET's Climate report 2012 which was stated to be $40.0^{\circ} \mathrm{C}$.

\subsection{Decadal Trend of Temperature in Yobe}

The results in Fig. 20 to Fig. 25 revealed that maximum temperature showed downward trends in decades (1956-1965; 1966-1975; 1986-1995 and 2006-2015) while it showed upward trends in the decades (1976-1985 and 1996-2005). The regression linear trend equations in Figs. 20-25 revealed that the mean maximum temperature in
Nguru and Potiskum decreased by $-0.15^{\circ} \mathrm{C}$ and $0.33^{\circ} \mathrm{C} ;-0.43^{\circ} \mathrm{C}$ and $-040^{\circ} \mathrm{C} ;-0.30^{\circ} \mathrm{C}$ and $-0.38^{\circ} \mathrm{C}$; $-0.25^{\circ} \mathrm{C}$ and $-0.39^{\circ} \mathrm{C}$ during the decades (19561965; 1966-1975; 1986-1995 and 2006-2015) respectively in Nguru. The figures also showed that the mean maximum temperatures increased by $0.26^{\circ} \mathrm{C}$ and $0.52^{\circ} \mathrm{C} ; 0.10^{\circ} \mathrm{C}$ and $0.22^{\circ} \mathrm{C}$ during the decades (1976-1985 and 1996-2005) in Nguru. This indicates that the mean maximum temperatures of the decades $(1956-1965 ; 1966-$ 1975; 1986-1995 and 2006-2015) were relatively cold while the temperatures of 1976-1985 and 1996-2005 were warmer during the period in both Nguru and Potiskum.

Similarly, the minimum temperatures for Nguru and Potiskum showed upward trends in the decades (1956-1965; 1966-1975; 1976-1985 and 2006-2015) while the decades (1986-1995 and 1996-2005) experienced downward trends. It could be observed from Figs. 20-25 also that the mean minimum temperatures increased by $0.45^{\circ} \mathrm{C}$ and $0.65^{\circ} \mathrm{C} ; 0.09^{\circ} \mathrm{C}$ and $0.02^{\circ} \mathrm{C} ; 0.85^{\circ} \mathrm{C}$ and $0.85^{\circ} \mathrm{C} ; 0.02^{\circ} \mathrm{C}$ and $0.12^{\circ} \mathrm{C}$ during the 
decades (1956-1965; 1966-1975; 1976-1985 and 2006-2015). In the same vein, the minimum temperatures decreased by $-0.17^{\circ} \mathrm{C}$ and -0.19 during the decades (1986-1995 and 1996-2005) respectively and by $0.07^{\circ} \mathrm{C}$ during the decade (1996-2005) in Potiskum. This also indicates that the minimum temperatures were warmer during the decades (1956-1965; 1966-1975; 1976-1985 and 2006-2015) compared to the decades (19861995 and 1996-2005).

This finding agrees with the finding of Oguntunde [12] which examined spatial and temporal temperature trends in Nigeria, 1901-2000 and concluded that the average annual temperature has risen by $0.3^{\circ} \mathrm{C}$ during the last century. Oguntunde [12] further stated that the warming trends were found to be more pronounced during the season (April -June). It was also stressed that the changes monthly minimum temperatures are more prominent than that of maximum temperature. This finding is equally in conformity with the finding of Hassan et al. [15] which revealed that the trends ranged from $0.04^{\circ} \mathrm{C}$ to $0.09^{\circ} \mathrm{C}$ per decade.
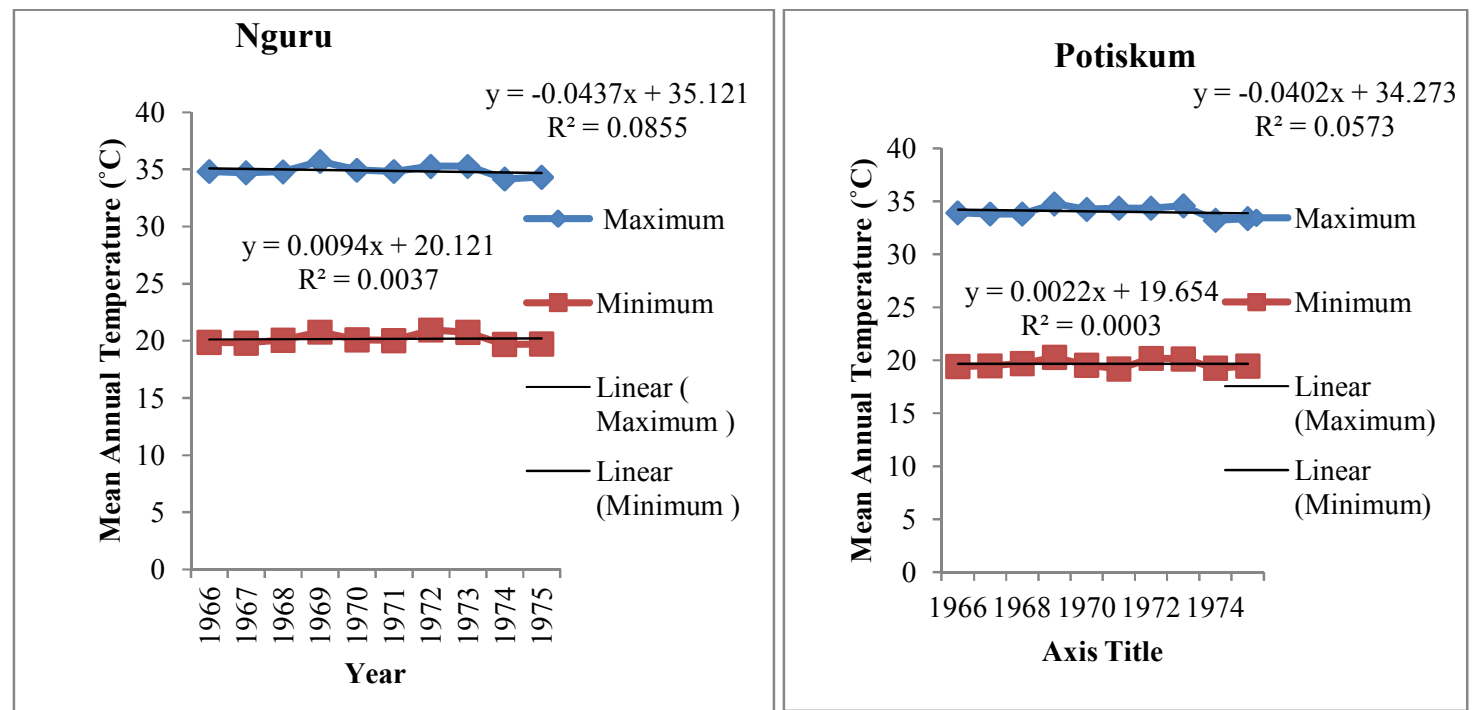

Fig. 21. Temperature trend in Yobe (1966-1975) Source: Authors' Fieldwork, 2021

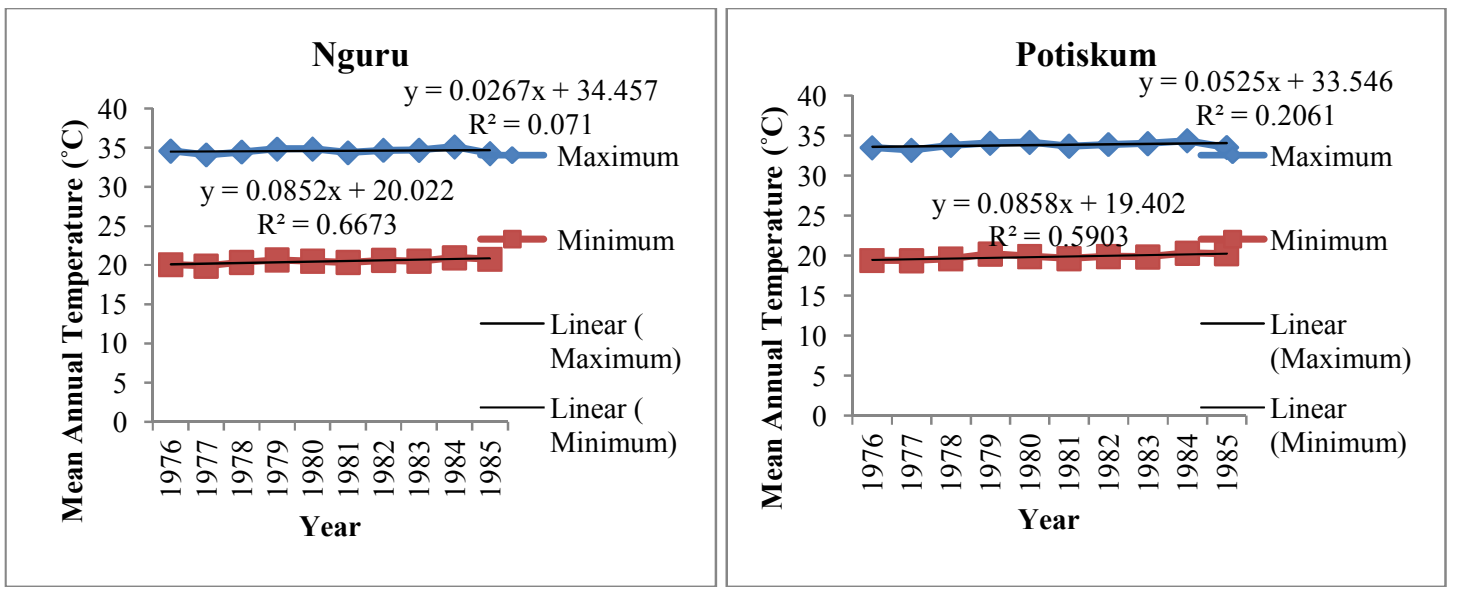

Fig. 22. Temperature trend in Yobe (1976-1985)

Source: Authors' Fieldwork, 2021 

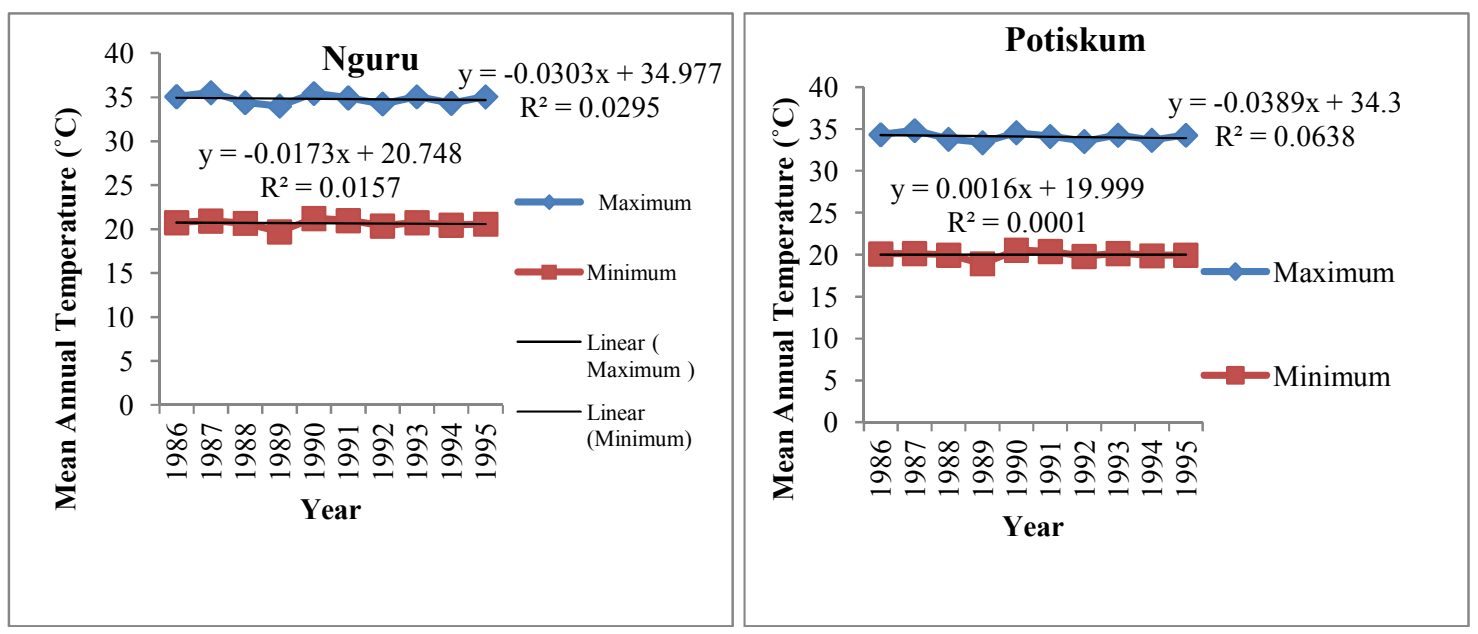

Fig. 23. Temperature trend in Yobe (1986-1995)

Source: Authors' Fieldwork, 2021

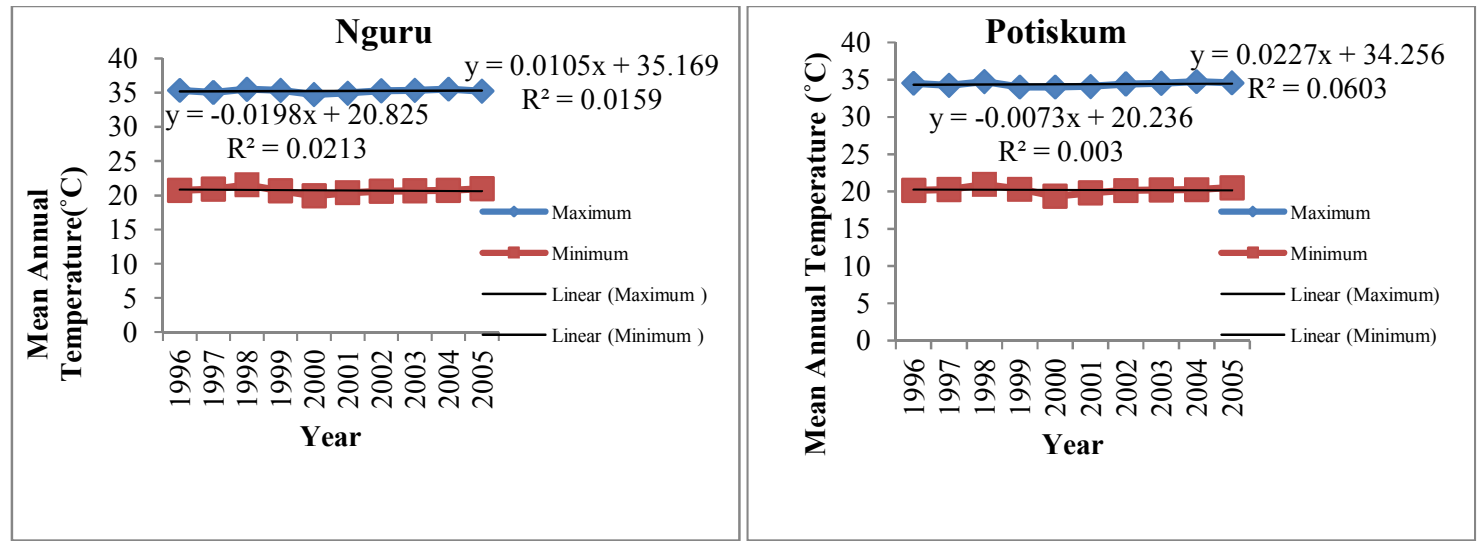

Fig. 24. Temperature trend in Yobe (1996-2006) Source: Authors' Fieldwork, 2021

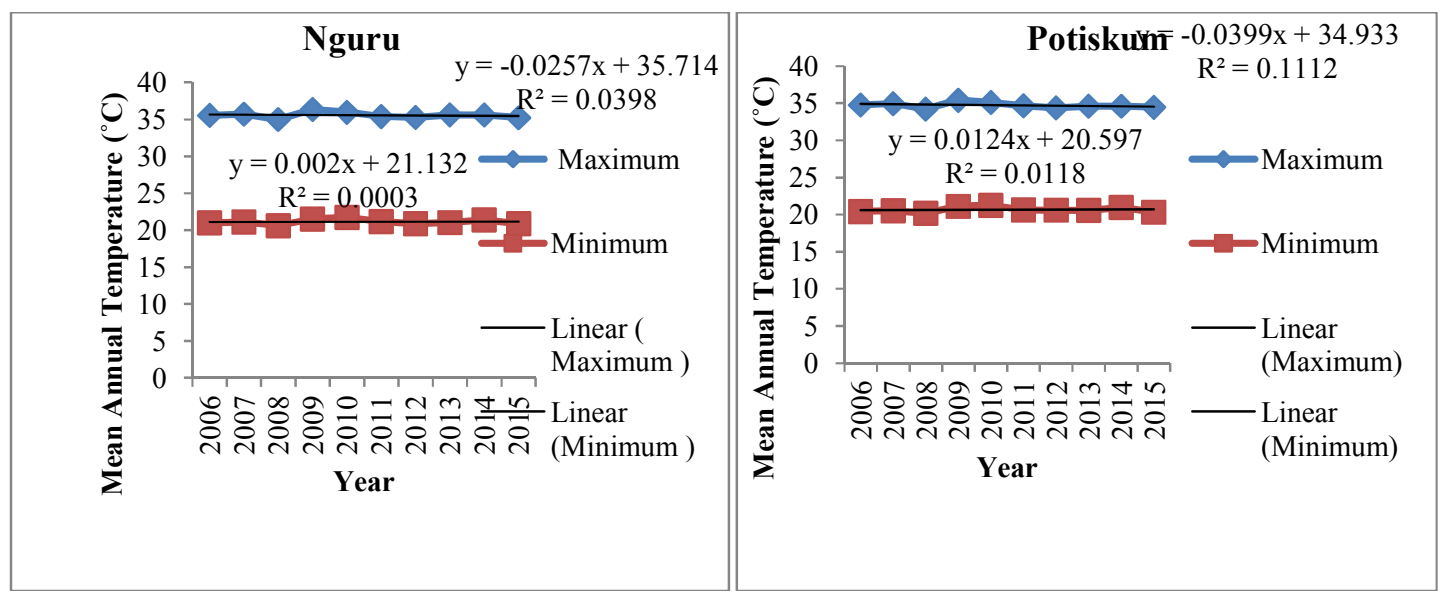

Fig. 25. Temperature Trend in Yobe (2006-2015)

Source: Authors' Fieldwork, 2021 


\subsection{Long-Term Trend of Temperature in Yobe (1956-2015)}

It could be inferred from Fig. 26 that both the minimum and maximum temperatures showed increasing trend in Nguru over the period (19562015). The regression trend equations on Fig. 26 showed clearly that the mean annual maximum and minimum temperatures in Nguru have increased by $0.6^{\circ} \mathrm{C}$ and $1.2^{\circ} \mathrm{C}$ per annum respective during the period.

The result in Fig. 27 also revealed that the mean annual maximum and minimum temperatures over Potiskum showed and increasing trend over the period (1956-2015). The regression trend equations in Fig. 27 revealed that the maximum and minimum temperatures in Potiskum have increased by $0.7^{\circ} \mathrm{C}$ and $1.3^{\circ} \mathrm{C}$ respectively during the period (1956-2015). This further implies that the temperature in Yobe is increasing and that portends increasing in hot condition in the State. This increasing trend is inimical to the physiological comfort and health of man, animals and other natural features in the area.

From the foregoing, there is no doubt about the fact that the temperatures in Yobe State have increased over the years. This finding correlates to the finding of Hassan et al. [15] which revealed that the annual temperature in Nguru and Potiskum showed positive trends. This is also in line with the assertion made by the IPCC [7] which stated that the trend of global temperature from $1951-2012$ is $0.12\left(0.08\right.$ to $\left.0.14^{\circ} \mathrm{C}\right)$ per decade. This finding corroborates with the finding of the IPCC (2013) which stated that the global trend over the past 15 years 1998-2012 was $0.05^{\circ} \mathrm{C}\left(-.0 .05\right.$ to $\left.0.13^{\circ} \mathrm{C}\right)$ per decade. All these reports showed strong evidence of increase in temperature in northeastern Nigeria. This finding is in agreement with the finding of Adeyeri [14] which stated that all overall positive trend is observed in warm day frequency, warm night frequency and warm spell duration while the cold night frequency has an overall negative trend over the places such as Bauchi, Diffa, Gombe, Kaduna, Katsina, Miduguri, Nguru and Potiskum. Warm day and warm frequencies have statistically positive trends for all the stations in the northeastern Nigeria between 1971 and 2017.

The increasing trends in the temperature for Yobe State will definitely have greater impacts on human, other natural resources as well as socioeconomic impact in the area. According to Serdesczny et al. [25] historical temperature increases have had substantial negative effects on agricultural value added in developing countries. A $1^{\circ} \mathrm{C}$ increase in temperature in developing countries has been found to be associated with $2.66 \%$ lower growth in agricultural output, leading to estimates of economic growth reductions by an average of 1.3 percentage points for each degree of warming [26] and reduction in export growth by 2.0-5.6 percentage points [27].

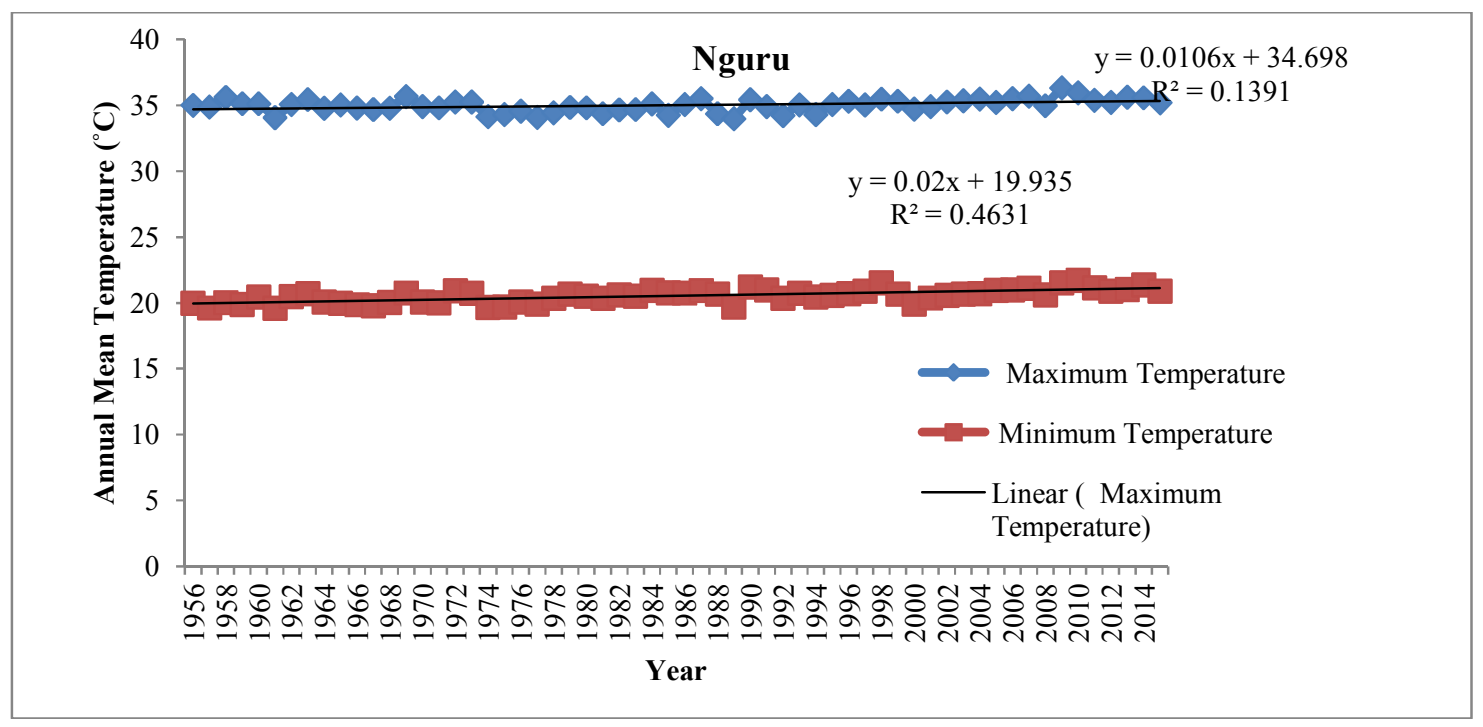

Fig. 26. Trend of annual temperature over Nguru, Yobe State (1956-2015) Source: Authors' Fieldwork, 2021 


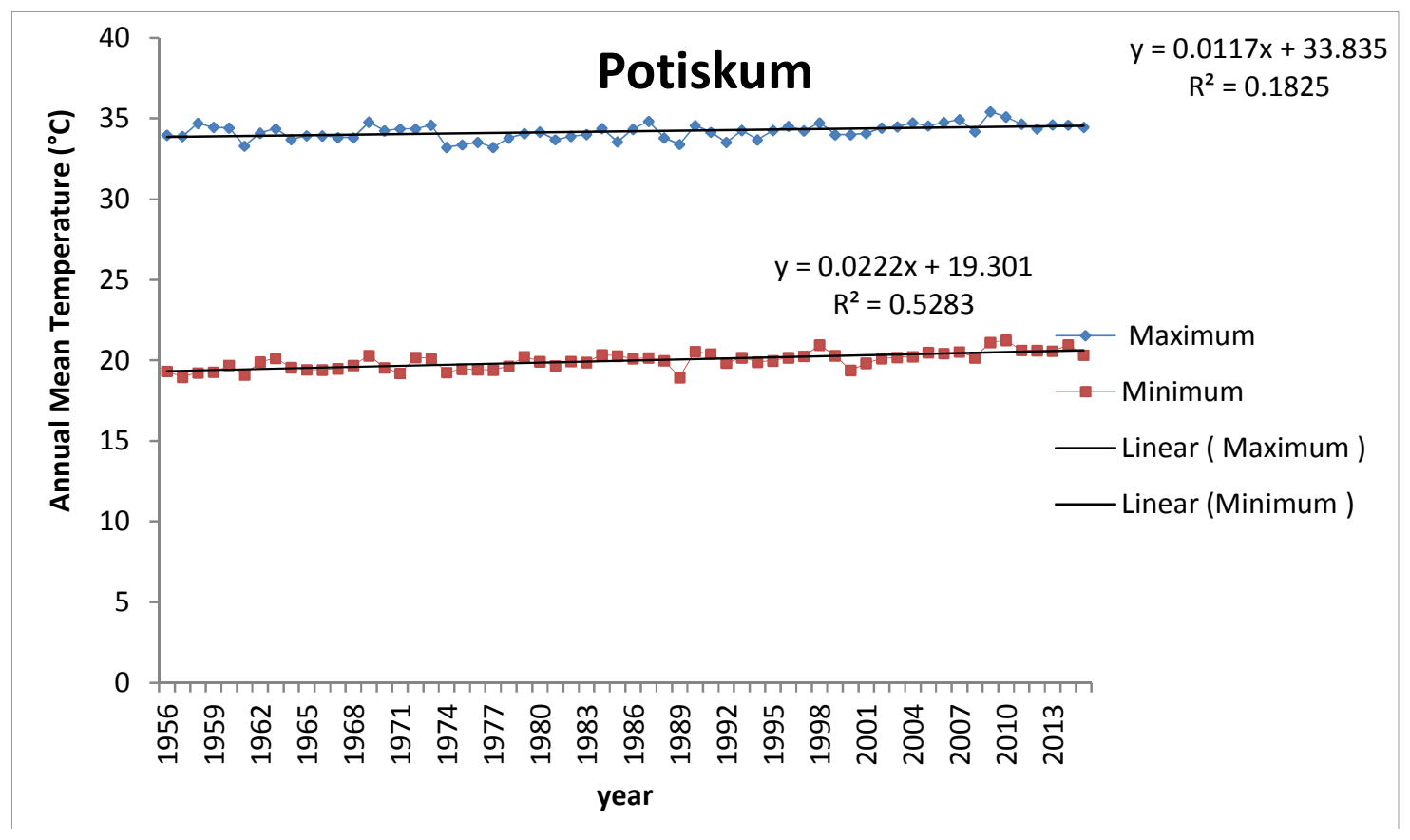

Fig. 27. Trend of annual temperature over Potiskum, Yobe State (1956-2015) Source: Authors' Fieldwork, 2021

\section{CONCLUSION AND RECOMMENDA- TIONS}

This study examined the changing patterns of temperatures in Yobe State and concludes that there were variations in the monthly, annual and decadal temperatures. It was discovered that April remained the hottest month while January remained the coldest month. Temperatures were highly variable during the month of February and less variable in September and October during the period. The decade 2001-2009 was the hottest decade during the period in Yobe State. In overall, there were upward trends in monthly and annual warmer conditions than normal. It is therefore suggested that stakeholders in the Yobe State Environmental Protection Agency should intensify efforts toward curbing deforestation while encouraging afforestation with a view to reducing the impact of Greenhouse gases that are contributing to the increase warming conditions. There should be adequate electricity supply for households to be able to effectively use appliances such as air conditioning and fans that can reduce heat on the body. Adequate water supply for drinking, washing and body shower for immediate relieve from excessive heat emanating from high temperature are recommended.

\section{COMPETING INTERESTS}

Authors have declared that no competing interests exist.

\section{REFERENCES}

1. Mahajan HK. Greenhouse gas emissions increase global warming. $\mathrm{J}$ Econ Pol Integration. 2011;1(2):21-32.

2. Mahajan HK. Global greenhouse gas emissions and climate change. Lambart Academic Publishing, Germany; 2013.

3. IPCC. Climate change: Impacts, adaptation and vulnerability, in: Parry, M., Canziani, O., Paulutikof, J., Van der Linden, P., Hassan, C (eds) Contribution of Eorking Group II to the Fourth Assessment Report of the International Panel on Climate Change, Cambridge UN-Press, Cambridge; 2007.

4. USEPA. Climate Change Indicators: Weather and Climate; 2017.

Retrieved 20 June 2020

Available:https://www.epa.gov/climatechan ge-indicators/weather- climate

5. Denchak M. Are the effects of global warming really that bad; 2016.

Retrieved 2 November 2019 
Available:https://www.nrdc.org/stories/arceffects-global-warming-really-that-bad

6. IPCC. Summary for policymakers of IPCC Special Report on Global Warming of $1.5^{\circ} \mathrm{C}$ approved by Governments; 2018.

Retrieved 29 June 2020

Available:https://www.ipcc.ch/2018/10/08/s ummary-for-policymakers-of-ipcc specialrepot-on-global.warming-of-1.5capprovedby-governmnents/

7. IPCC. Climate change 2014: Synthesis report. Contributions of working Groug I, II and III to the Fifth Assessment Report of the Intergovernmental Panel on Climate Change (Core Writing Team, Pachauri and Meyer, L. A.(eds.)): IPCC, Geneva, Switzerland. 2014;151.

8. Kotir $\mathrm{JH}$. Climate change and variability in Sub-Saharan Africa: A review of current and future trends and impacts on agriculture and food security. J Env Dev Sustainability. 2011;13(3):587-606.

9. Adefolalu DO, Pam JL, Habbi HM. Climate change and state of air transportation-a nigerian perspective. In: Proceedings of the International Conference on the Impacts of Extreme Weather and Climate on Socio-economic Development in Africa held at the Federal University of Technology, Akure, Nigeria. 2007;1-15.

10. Ikhile Cl. Impacts of climate variability and change on the hydrology and water resources of the Benin-OWENA River Basin. PhD Thesis Submitted to the Department of Geography and Regional Planning, University of Benin. Binin City, Nigeria; 2007.

11. Odjugo AO. Regional evidence of climate change in Nigeria. J Envi Earth Sci. 2010;5(10).

12. Oguntunde PG, Abiodun BJ, Lischeid G. Spatial and temporal trends in Nigeria, 1901-2000. J Meteo Physics. 2012;188:95105.

13. Sawa BA, Ati OF, Jaiyeoba IA, Oladipo EO. Trends in aridity of the arid and semiarid regions of northern Nigeria. J Envi Earth Sci. 2015;5(10).

14. Adeyeri OE, Lawin $A E$, Laux $P$, Ishola KA, Ige SO. Analysis of climate extreme indices over the Komadugu-YobeBasin, Lake Chad Region: Past and Future Occurences. Elsevier B. V. 2009;121.
15. Hassan SF, El-Tantawi AM, Hashidu US. Trends of rainfall and temperature over northeastern Nigeria (1949-2014). Journal of Envi Sci, Toxicology Food Tech (IOSRJESTFT. 2017;11(5):01-09.

16. Yusuf N, Okoh D, Musa I, Adedoja S, Said R. A study of the surface air temperature variation in Nigeria. J Atmospheric Sci. 2017;11:54-70.

17. Zembe AA, Umar Y, Bimbol NL. Climatic information as an evidence of desertification processes in northern Yobe State, Nigeria: Implications for agriculture and ecosystem. J Pure Applied Sci. 2018; 24(2018):117-124.

18. National Population Commission; 2006.

19. Yobe State (n.d) in Wikipedia.

Retrieved 24 June 2020

Available:htts://en.m.wikipedia.org/wiki/yob e-state.

20. Akinsanola AA, Ogunjobi KO. Analysis of rainfall and temperature variability over Nigeria, J Human Soc Sci. 2014;14(3):118.

21. Nigerian Meteorological Agency. Annual Seasonal Rainfall Prediction (SRP). Publication of by the Nigerian Meteorological Agency and National Weather Forecasting and Climate Research Department, Nnamdi Azikiwe International Airport Abuja. 2020; 1-46.

22. Nigerian Meteorological Agency. Quarterly weather review (January, February, March). Publication of the Nigerian Meteorological Agency, National Weather Forecasting and Climate Research Center, Nnamdi Azikiwe International Airport Abuja. 2013;021:1-28.

23. Agrometeorological Bulletin. Quarterly compilation of agromet decadal (AprilJune). Published by Nigerian Meteorological Agency. 2012;3-30.

24. Abdussalam AF. Changes in induces of daily temperature and precipitation extremes in north-west Nigeria. Science World Journal. 2015;10(2):102-222.

25. Serdesczny O, Adams S, Baarsch F, Coumon D, Robinson A, Hare W, Schaeffer M, Perrette M, Reinhardt J. Cliate change impacts in Sub-Saharan Africa: From physical to their social repercussions. J Regional Envi. Change. 2015;15(8):1-19. 
26. Dell M, Jones BF. Temperature shocks and economic growth: Evidence from the last half century. $\mathrm{J}$ American Econ Macroeconomics. 2012;

27. Jones BF, Ollken BA. Climate shocks and vulnerability to climate extremes: population and assets exposure to coastal flooding in Dar es Salaam, Tanzania. J 4(3):66-95. Regional Env Change. 2010;12(1):81-94.

(c) 2021 Kehinde et al.; This is an Open Access article distributed under the terms of the Creative Commons Attribution License (http://creativecommons.org/licenses/by/4.0), which permits unrestricted use, distribution, and reproduction in any medium, provided the original work is properly cited.

Peer-review history:

The peer review history for this paper can be accessed here: http://www. sdiarticle4.com/review-history/66372 